\title{
K OTÁZCE KOSTELNÍCH VĚŽÍ
}

\author{
MILENA HAUSEROVÁ
}

\begin{abstract}
Abstrakt: $V$ diskusi o počátcich našich vrcholně středověkých hradů byl vysloven názor, že rané stadium hradu v našich podminkách představuji románské tribunové kostely se západní věži Kostelní věž v rámci této hypotézy odkazuje ke svému profánnímu původu. Příspěvek otevírá prostor diskuse s některými argumenty, s nimiž koncept kostela se západni věži jako předstupně hradu pracuje. Uvádi u nás neznámé př́klady rozšiření románských kostelů se západními věžemi zejména ze západni Evropy. Výběr dokladů sakrální funkce a posvátné symboliky kostelni věže nabizi komplementární část pohledu na jeji význam. Budování věži v sídlech elit a věži kostelních uvádi do časové souvislosti. Obrací pozornost k etapizaci výstavby kostelů, která objasňuje vzájemné postavení některých samostatně stojícich věži a kostelních lodí. Reaguje na možnost srovnáváni se skandinávskými přiklady. Dotýká se polyfunkčnosti středověkých staveb, která neoslabuje jejich dominantni sakrální určení.
\end{abstract}

Klíčová slova: hrad-tribunový kostel-věž - zvonice - westwerk.

\section{On the issue of church towers}

\begin{abstract}
The discussion about the origins of Czech castles from the high Middle Ages involved an opinion that the early stage of castles in the conditions of this country was represented by Romanesque tribune churches with a west tower. In this hypothesis, the church tower refers to their secular origin. The paper opens up space for a discussion regarding some of the arguments associated with the concept of churches with west towers as predecessors of castles. It gives examples of the spread of Romanesque churches with west towers unknown in this country, especially from western Europe. The selection of evidence of the sacral function and sacred symbolism of the church tower offers a complementary part of the view of its significance. The article sets the building of towers in the residences of the elites and church towers in a chronological context. It discusses the phasing of church construction which clarifies the related position of some of the free-standing towers and church naves. It responds to the possibility of comparisons with Scandinavian examples and touches upon the multifunctionality of medieval buildings which, however, does not weaken their dominant sacral purpose.
\end{abstract}

Key words: castle-tribune church-tower-bell tower-westwerk.

\section{Kontext diskusního př́íspěvku zaměřeného na románské kostely a jejich věže}

Současné pokusy o objasnění procesu, v němž se formovala šlechta vrcholného středověku, se odehrávají jak v rovině diskuse o genezi šlechty samé, tak pochopitelně i v rovině zkoumání všech jevů, které by mohly př́tomnosti nobility nasvědčovat. Za jeden z významných projevů výlučného společenského postavení lze bezpochyby pokládat reprezentační sídlo. Obraz středověku v obecné rovině charakterizuje spojnice mezi pozemkovou šlechtou a jejím sídlem - hradem. V těchto souvislostech vyvstává legitimní otázka: Jak to bylo se sídly této rané nobility u nás v době, kdy západně od nás si šlechta již vrcholně středověké hrady stavěla? Otázkou „Co je kostel?"“ nabídl F. Laval (2016, 47-90) nový pohled na diskutované téma rané nobility. Laval usiluje o zvyklostmi nezatížený postoj $\mathrm{k}$ výpovědi historických pramenů různé povahy včetně pramenů hmotných. Nový pohled na románský kostel se západní věží představuje jednu z opor předloženého konceptu. Nabízí názor, že na kostel tohoto uspořádání lze pohlížet jako na předstupeň hradu. Genezi kostela spatř́uje v procesu splývání věže profánního účelu se soukromou svatyní v rámci velmožského sídla. Svou představu této vývojové linie dokládá výběrem př́íkladů ze sakrálního i profánního prostředí. Na nich předvedl různé způsoby kontaktu či propojení profánní věže a svatyně. Vyslovil myšlenku, že kostelní věž jako stavební typ byla součástí kulturních inovací, které nástup hradů ohlašují. Kostelní věži přičítá, stejně jako u hradních bergfritů, především význam refugia a statutárního symbolu. Jeho představa spojnice mezi románským 
kostelem a hradem byla již v nedávné době akceptována jako vhodný teoretický rámec $\mathrm{k}$ další diskusi (Hasil-Novák 2020, 846). Tento př́spěvek upozorňuje na některé aspekty, které v Lavalově studii při interpretaci kostela ustoupily do pozadí nebo byly pominuty, a nabízí k některým z pojednávaných jevů odlišný výklad. Vstupuje tak do diskuse o roli kostela připomínkou jeho dalších významů. Poukazuje na málo známé paralely raných románských kostelů se západními věžemi mimo území našeho státu, které staví u nás dochované doklady drobných románských sakrálních staveb do dosud nezkoumaných souvislostí. V textu pojednávaná témata si nekladou za cíl nabídnout ucelený obraz románského kostela u nás, ale nabízejí materiál k další diskusi nad některými názory uvedenými v Lavalově studii. S ohledem na vypovídací možnosti staveb, které sice dokládají podobu dějiště historického procesu, ale nesvědčí již př́imo o konkrétních dějích ani o jejich pohnutkách, však příspěvek již přímo nevstupuje do té roviny diskuse, jež tyto poznatky zapojuje do názoru na charakter tehdejších celospolečenských proměn. S ohledem na své oborové východisko zakotvené v dějinách stavební kultury se proto také nedotýká problematiky postavení a funkce těchto svatyň v prostředí rodící se církevní správy, která by jinak měla tvořit paralelní téma v diskusi o vztahu románského kostela a hradu.

\section{Role věže a tribuny v diskusi o významu románského kostela}

Lavalova úvaha se odvíjí od podobnosti stavebních útvarů některých hradních a jiných elitních sídel v západním kulturním prostředí s románskými kostely s věží připojenou k západní zdi lodi (Laval 2016, 58).

Hrady ale nebyly jediným typologickým druhem staveb, v nichž se věž uplatňovala. Vedle civilních staveb různého účelu věže zvýrazňovaly i výstavné sakrální stavby. V prostředí latinské církve a okruhu jejího působení věž představovala jejich dlouhodobě zažitý atribut naplněný symbolickými významy. Pluralita významů věže se tedy stává podstatným aspektem diskuse.

Zděný románský jednolodní kostel se západní věží připojenou k západnímu průčelí lodi představuje jednu z početnějších variant stavební podoby drobných románských svatyň. Tribuna je stavebním útvarem, s nímž se v různé míře dochování setkáváme ve většině z nich. Její poloha, utváření i komunikační vazby s lodí kostela a s jeho exteriérem jsou u kostelů se západní věží různými způsoby provázány s jejím tělesem. Historie i současný stav poznávání geneze, významu a fungování západní věže románského kostela jsou proto zásadním způsobem propojeny s výzkumem vzniku a funkce tribun a tribunového kostela jako celku. V následujícím textu proto budou tyto aspekty provázány.

\section{Stav poznání románských tribunových jednolodních kostelů se západní věží}

Ve známé stati o panských tribunách V. Mencl (1965) přičetl roli hlavního inspiračního zdroje tribunových řešení západním partiím karolínských dómů a benediktinských klášterních kostelů (obr. 1). Různými sestavami věží těchto karolínských chrámů a kostelů, které na ně navázaly, byly zvýrazněny jak západní, tak východní části dvouchórových dispozic, popř́ípadě chrámů s westwerky. Vertikála jedné nebo více věží se stala charakteristickou součástí architektonického aparátu, který zdůrazňoval zvláštní funkci a význam západní strany takto uspořádaných kostelů. Důraz na působivý výraz západní strany těchto reprezentačních staveb se tradičně uváděl do souvislosti s vladařskou reprezentací. Kritiku tradičního chápání „westwerku“ a jeho zatížení neúměrným zdůrazňováním imperiální symboliky, kterou pěstovala starší německá uměnověda, nabídla Schönfeld de Reyes (1999).

V. Mencl soudil, že monumentální západoevropské vzory spojuje s tribunovými kostely středovýchodní Evropy dnes již nepostižitelný proces redukce. S použitím znaků napodobovaných staveb chápaných ve své době jako významné a charakteristické dala tato proměna vzniknout stavebnímu řešení odlišného formátu a posunutého významu. Sám princip středověkého procesu napodobení, který se nemusel zakládat na prrímé vzhledové podobnosti vzoru a obrazu, 


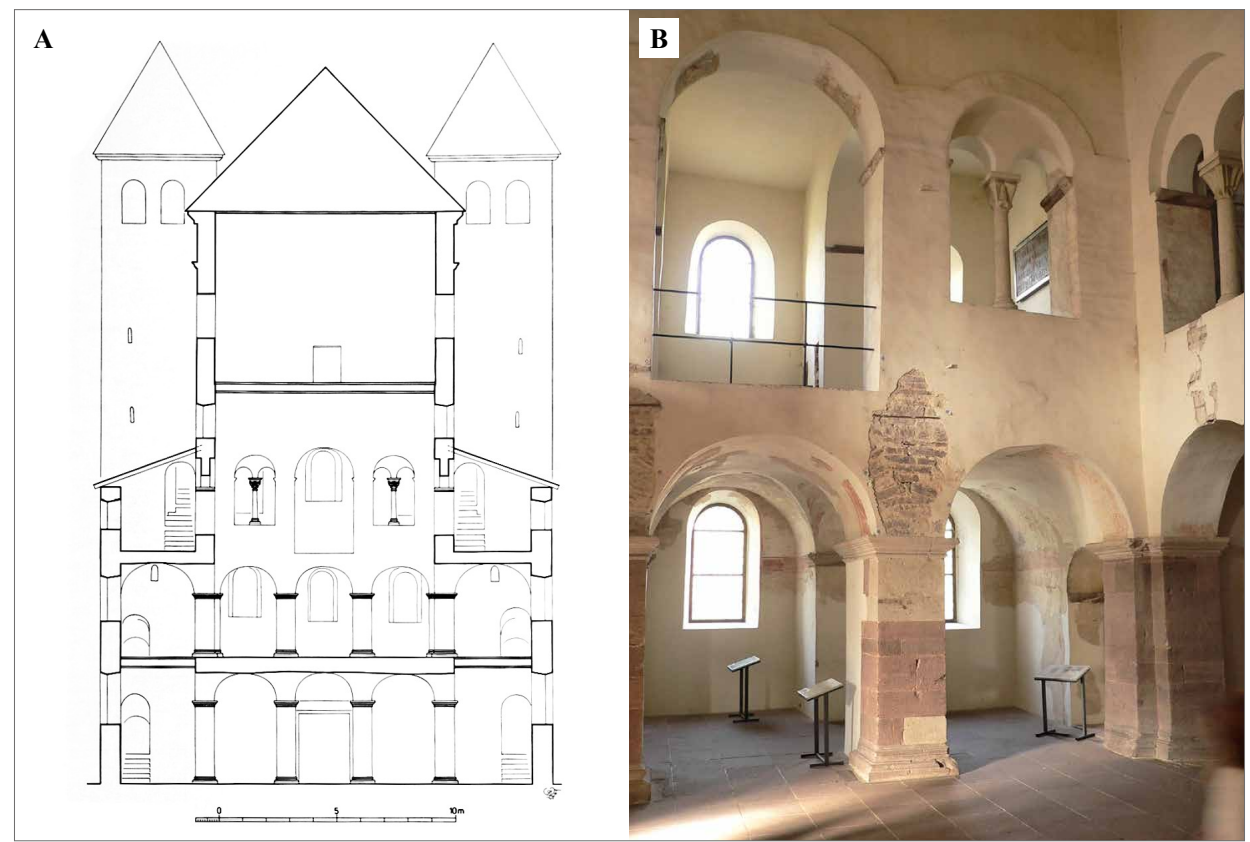

Obr. 1. Westwerk klášterního chrámu v Corvey. A - rekonstrukce stavu v době karolínské, řez s pohledem k západu (podle Clausen 2002, 21); B - pohled na tribunu na západní straně horního patra westwerku (foto M. Hauserová).

Abb. 1. Westwerk der Klosterkirche in Corvey. A - Rekonstruktion des Zustandes zur Karolingerzeit, Schnittdarstellung mit Blick von Westen (nach Clausen 2002, 21); B - Blick auf die Empore an der Westseite des oberen Stocks des Westwerks (Foto M. Hauserová).

rozvedl již G. Bandmann (1951, 48). Menclovu představu vzniku tribunových kostelů redukcí monumentálních vzorů sledovali A. Tomaszevski, G. Entz a P. Tajkov (2010). Tito autoři se zabývají tribunovými kostely na území Čech, bavorského příhraničí, Polska a Uher. Výskyt kostelů téhož typu v západní Evropě a ve Skandinávii nezmiňují. O souvislosti skandinávských kostelů se západními věžemi a emporami s karolínskými předobrazy a jejich odvozeninami rovněž nepochybuje skandinávská literatura. Zmínky o širším výskytu staveb tohoto typu v Evropě v ní však chybí (obr. 2). Povědomí o souvislosti tzv. panské tribuny románských kostelů se západní částí karolínských dómů v současné době představuje významnou součást náhledu české, slovenské, polské, mad’arské i skandinávské literatury na románský tribunový kostel (obr. 3). Menclův postřeh (obr. 4A, B), že tribuna představovala svého druhu soukromou kapli, která byla vložena do organismu farního kostela, však již další autoři nerozvíjeli. Nový aspekt do výkladu funkce západní tribuny malých románských kostelů středovýchodní Evropy (Polsko, Čechy, Uhry) přinesl A. Tomaszewski (1974). Na rozdíl od představy císařské a přeneseně mocenské reprezentace tradičně spojované s westwerky (souhrnně Grossman 1957, 253-264; Schönfeld de Reyes 1999) sledoval i využití prostor westwerků v dobové liturgii a v dalších mimoliturgických rolích včetně otázky propojení kostela se souvisejícím sídlem. $\mathrm{Na}$ základě popisu velikonoční bohoslužby v St. Riquier v Centule upozorňoval na mezery v porozumění liturgickým zvyklostem praktikovaným ve stavbách karolínském okruhu a jejich odvozeninách. Připomíná živou tradici stacionární bohoslužby s průvody věřících po skupinách kostelů. Odvozeně takové průvody procházely uvnitř jediného kostela od oltáře k oltáři včetně oltářů v jeho západní části (Baldovin 1987). Liturgickému provozu západních partií kostela se dále věnovala K. Krüger (2003; 2003a). Nově na význam tradice raných liturgických zvyklostí upozornila v úvodní studii publikace Stredoveký kostol B. Pomfyová (2015). Současný výzkum 
raně křest’anských reziduí ve středověkých liturgických zvyklostech nasvědčuje tomu, že snaha o porozumění liturgickému provozu ve středověkém sakrálním prostoru může ještě značně pozměnit vžité představy. Tomaszewski ve své práci vybízel k obezřetnosti před pokusy o př́liš jednostranný výklad smyslu a funkce západních tribun. Výzkumy západních částí městských
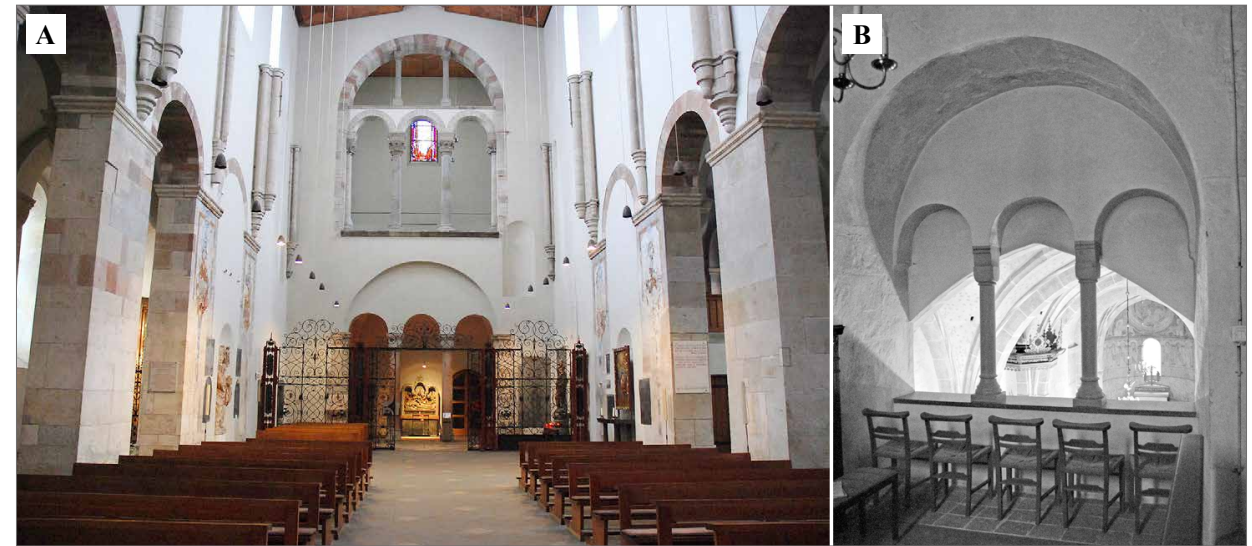

Obr. 2. Ohlasy karolínských inspirací. A - Panna Maria na Kapitolu, Kolín nad Rýnem, před 1075, tribuna v západní věži kostela s citací arkádového motivu z korunovační kaple Karla Velikého v Cáchách - příklad tradice používání zdủrazněné západní věžové partie u velkých románských sakrálních staveb z Porýní (zdroj Wikimedia commons); B - Fjelie, Loma, Švédsko, po 1130, pohled z tribuny v západní věži do lodi kostela s mladší vloženou klenbou (podle Hansen 2013, 183).

Abb. 2. Anklänge an karolingische Inspirationen. A - St. Maria im Kapitol, Köln am Rhein, vor 1075, Empore im Westturm der Kirche mit Zitaten des Arkadenmotivs aus der Pfalzkapelle Karls des Großen in Aachen - Beispiele für die Tradition, bei großen romanischen Sakralbauten im Rheinland die westliche Turmpartie hervorzuheben (Quelle Wikimedia commons); B - Fjelie, Loma, Schweden, nach 1130, Blick von der Empore im Westturm ins Kirchenschiff mit jüngerem eingefügten Gewölbe (nach Hansen 2013, 183).

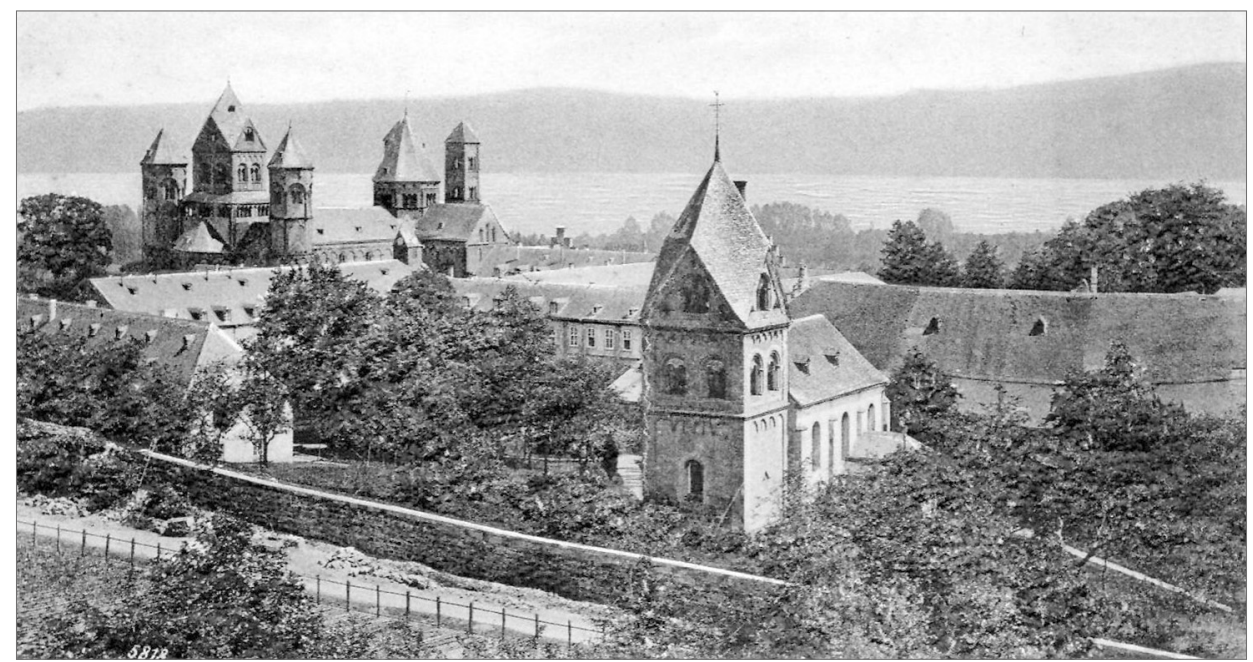

Obr. 3. Monumentální architektura a její redukce. Klášterní chrám v Maria Laach (dokončen kolem 1200 - v pozadí) a v návaznosti na něj vybudovaný laický kostel sv. Mikuláše vně klausury (zachována jen věž, lod' z poloviny 18. století - v popředí). Snímek stavu kolem roku 1900, před puristickou úpravou. Zdroj Wikimedia commons.

Abb. 3. Monumentalarchitektur und ihre Reduktionen. Klosterkirche in Maria Laach (um 1200 fertiggestellt - im Hintergrund) und die in Anknüpfung an sie errichtete St. Nikolaus-Laienkapelle außerhalb der Klausur (erhalten geblieben nur der Turm, das Schiff aus der Mitte des 18. Jhdts. - im Vordergrund). Aufnahme des Zustandes um 1900, vor der puristischen Umgestaltung. Quelle Wikimedia commons. 


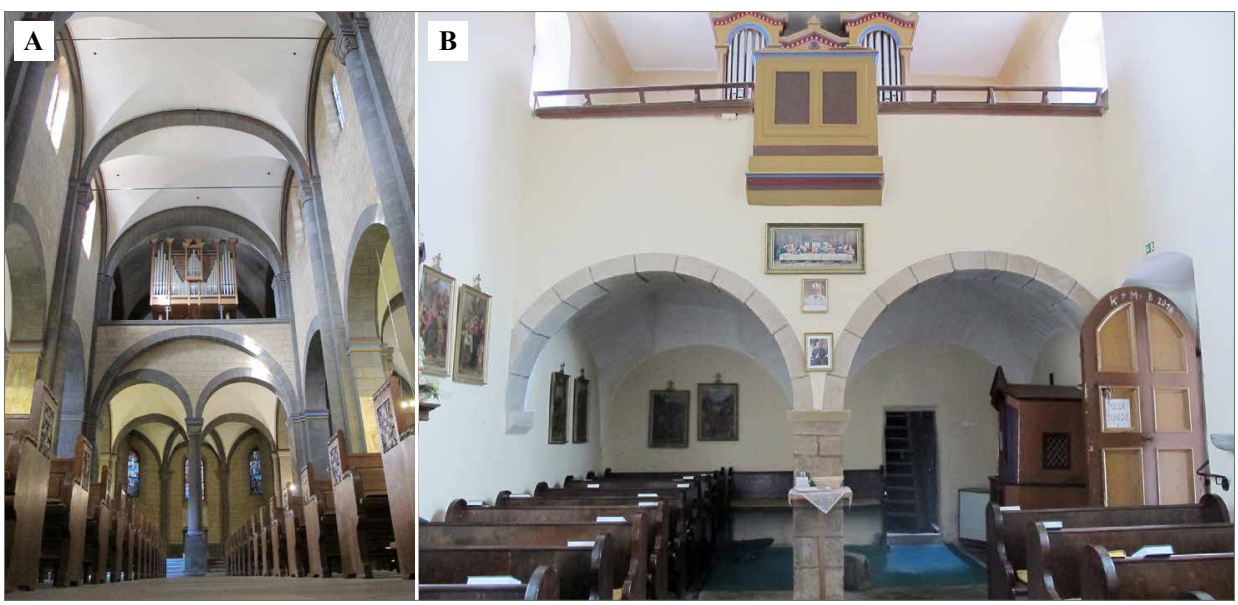

Obr. 4. Odvozenina dílčího architektonického motivu. A - západní tribuna v monumentální románské architektuře klášterního kostela v Maria Laach; B - tribuna románského venkovského kostela v Chřenovicích. Foto M. Hauserová.

Abb. 4. Ableitungen eines architektonischen Einzelmotivs. A - Westempore in der romanischen Monumentalarchitektur der Klosterkirche in Maria Laach; B - Empore der romanischen Dorfkirche in Chřenovice. Foto M. Hauserová.

kostelů a jejich výzdoby zejména v severním Německu a zvláště prostorů při západních portálech a kaplí situovaných ve věžích nad nimi ukazují na roli těchto prostor v právních úkonech (Rimpel 2011). Nejnověji názory Tomaszewského rozvinula B. Pomfyová (2011), která vytěžila poznatky zahraničního bádání k problematice západních partií kostelů a diskusi k westwerkům. V jejím pohledu nabývá liturgická funkce tribuny na významu, i když zároveň kriticky přiznává trvající interpretační nejistoty.

Dílčí výzkumy v českých zemích rozhojnily soubor př́kladů uzavřených věžních tribun s oltářními nikami, které dokládají jejich liturgické využití. Př́ítomnost oltáře byla do jejich identifikace známa jen $\mathrm{z}$ nečetných stop $\mathrm{v}$ parapetech tribun. Zjištěné a dokumentované doklady stop komunikačních vztahů mezi lodí kostela a věží vyvrátily názor, že prostor tribuny a lod' kostela představovaly dva odlišné světy, které spolu nekomunikovaly (Klápště 2005, 65). První patro věže naopak vystupuje jako klíčový komunikační uzel, který s vnějškem kostela propojuje nejen horní partie věže a případně i podstřeší lodi, ale i lod' kostela. Předmětem studia se stal i směr těchto komunikačních vazeb (Prix-Všetečková 1993; Čechura 2002).

Rostoucí poznání předpokladů pro šíření stavební kultury znovu docenilo význam řádových stavebních podniků a sítí vztahů, jimiž byly propojeny mezi sebou. Jisté korekce zaznamenává i starší představa o postupném rozptylu „vlivư“ z významných center do jejich zázemí. Konkrétní, i když nepočetné prŕíklady nasvědčují tomu, že kontakt stavebníků románských kostelů s nositeli nezbytné stavební a výtvarně-řemeslné dovednosti nebyl zdaleka odkázán na zdlouhavý proces difuze. Jejich role ve světle hlouběji zkoumaných př́ikladů nabývá aktivnější podoby, než kterou jí přisuzoval podhled uměnovědy založený na studiu příbuznosti architektonických forem a výtvarné výzdoby (Hauserová-Nováček-Čechura-Falta 2011; Hauserová 2012; Nováček 2010, 181-182). Více než půlstoletí stará Menclova charakteristika limitů, které v jeho době komplikovaly srovnávací výzkum, bohužel zůstává do značné míry stále platná. Dokumentace a průzkumy drobných venkovských kostelů $\mathrm{v}$ regionech podstatných pro studium sledovaného tématu zůstávají rozptýleny převážně v regionální literatuře a v nepočetných studiích věnovaných jednotlivým objektům. Soubornější zpracování jsou stále spíše vzácná. Následkem toho ani nevyvstala otázka, do jaké míry lze v západní Evropě dohledat paralely k románským jednolodním kostelům se západní věží známým ze středovýchodní Evropy a jakou vzájemnou souvislost by případně tyto stavby mohly mít. 


\section{Příklady malých tribunových kostelů se západní věží z okruhu působení karolínských vzorů}

V Československu, Polsku a Mad’arsku se románské tribunové kostely staly zejména v období po druhé světové válce předmětem badatelského zájmu díky tomu, že náležejí k nepočetným dokladům stavební kultury raného středověku dochovaným ve fyzické realitě dosud stojícího, i když často přestavbami zasaženého stavebního díla. Podobná motivace vedla k časnému výzkumu středověkých kostelů ve Skandinávii. V prostředí studia západoevropské sakrální architektury s početně dochovanými památkami monumentální architektury zůstávají drobné románské stavby na venkově spíše sférou zájmu regionálního výzkumu. Na románský kostel na venkově středovýchodní Evropy se při nedostatečné konfrontaci se srovnávacím materiálem stále pohlíží jako na izolovaný fenomén, který se přes uznávanou souvislost s časově i místně vzdálenými ř́šskými předobrazy stal projevem lokální tvořivosti (Prix 2009, 32) a odrazem specifiky místních církevních poměrů. S výjimkou Idensen nejsou př́klady z Porýní, Flander ani Skandinávie v české odborné literatuře známé. Dokládají přitom souběžný výskyt typu malých tribunových kostelů se západní věží v západní a středovýchodní i severní Evropě. Otevírají prostor nejen dalšímu srovnávacímu výzkumu, ale i otázkám po genezi tohoto stavebního typu.

$\mathrm{Na}$ kostel v Idensen (obr. 5A, B) jako na paralelu k polskému kostelu ve Wysocicích s uzavřenou tribunou-kaplí situovanou v patře západní věže upozornila v polovině 90 . let M. Radová (1996). Z hlediska sledovaného tématu je kostel v Idensen významný svou charakteristickou hmotovou skladbou jednolodní svatyně se západní věží, poměrně přesnou datací svého vzniku, vědomým a srozumitelným odkazem na karolínské vzory i známou osobností svého stavebníka. Tribunový kostel u svého dvorce v Idensen nechal v rozmezí let 1120 až 1140 zbudovat mindenský biskup Sigward, který zde byl v roce 1144 také pohřben. Sigward patřil do okruhu nejbližších rádců císaře Lothara III. V jeho průvodu se seznámil s předními centry říše a jejich kulturou. Ve výtvarné koncepci jeho kostela i v jeho mimořádné malířské výzdobě současný uměnovědný výzkum identifikuje odkazy, které v době svého vzniku srozumitelně vyjadřovaly stavebníkův vztah k otonské tradici (Lawrenz 2003, 226-231). Původní zasvěcení Sigwardova kostela 11000 pannám dovoluje vést nejen formální, ale i významovou spojnici ke kolínskému kostelu P. Marie na Kapitolu budovanému pod záštitou císaře Oty II., kde byly uchovávány ostatky těchto mučednic (Pfeiffer 1990). Hledání významové souvztažnosti obou staveb se však omezilo na výtvarnou výzdobu a uspořádání východní části kostela. Ke vztahu západní partie kolínského vzoru s tribunou v patře $\mathrm{k}$ tělesu západní věže v Idensen se nevyjadřuje. Soukromá kaple v patře této věže s oltářem zasvěceným sv. archandělu Michaelovi byla přístupná jak přímo z exteriéru kostela portálem ze severní strany věže, tak z přízemí lodi schodištěm v tloušt'ce zdi. Kaple zaujímá celé první patro věže a zjevně ovlivňuje její značné půdorysné rozměry.

Hustý výskyt románských blíže nedatovaných kostelů s mohutnými západními věžemi v okolí Minden (Wurm, Ludorff 1902) nasvědčuje tomu, že Sigwardova svatyně představuje variantu regionálně rozšśřreného typu kostela (Günther 2010, 123). Ke zřetelným paralelám Sigwardova kostela náleží kostel sv. Bartoloměje ve Wunstorfu (ca $5 \mathrm{~km}$ od Idensen). Nese některé shodné motivy kamenické práce. Vyznačuje se rovněž mohutnou hranolovou západní věží. Wunstorf byl ale na rozdíl od Idensen již ve 12. století sídlem městského typu. Bližší datování dalších románsky vyhlížejících staveb obdobného uspořádání je však bez podrobnějších průzkumů nesnadné. Není proto zatím možné posoudit, zda Sigwardův kostel měl pro podobu těchto kostelů iniciační roli, nebo naopak rozvinul již známé řešení.

Věžní kaple podobná kapli Sigwardově zaujímá první patro západní věže v nedalekém Wollersheimu (Dehio 2005, 1189; obr. 8). Úspornější stavební provedení rezignovalo na vedení schodiště do patra věže v tloušt'ce její zdi. Vystačilo si s jednodušším lehkým schodištěm vedeným z prostoru zaniklé lodi. Kaple byla př́stupna na úrovni patra i z vnějšku, stejně jako Sigwardův kostel. Wollersheim náležel k prvotní hospodářské výbavě významného ženského 


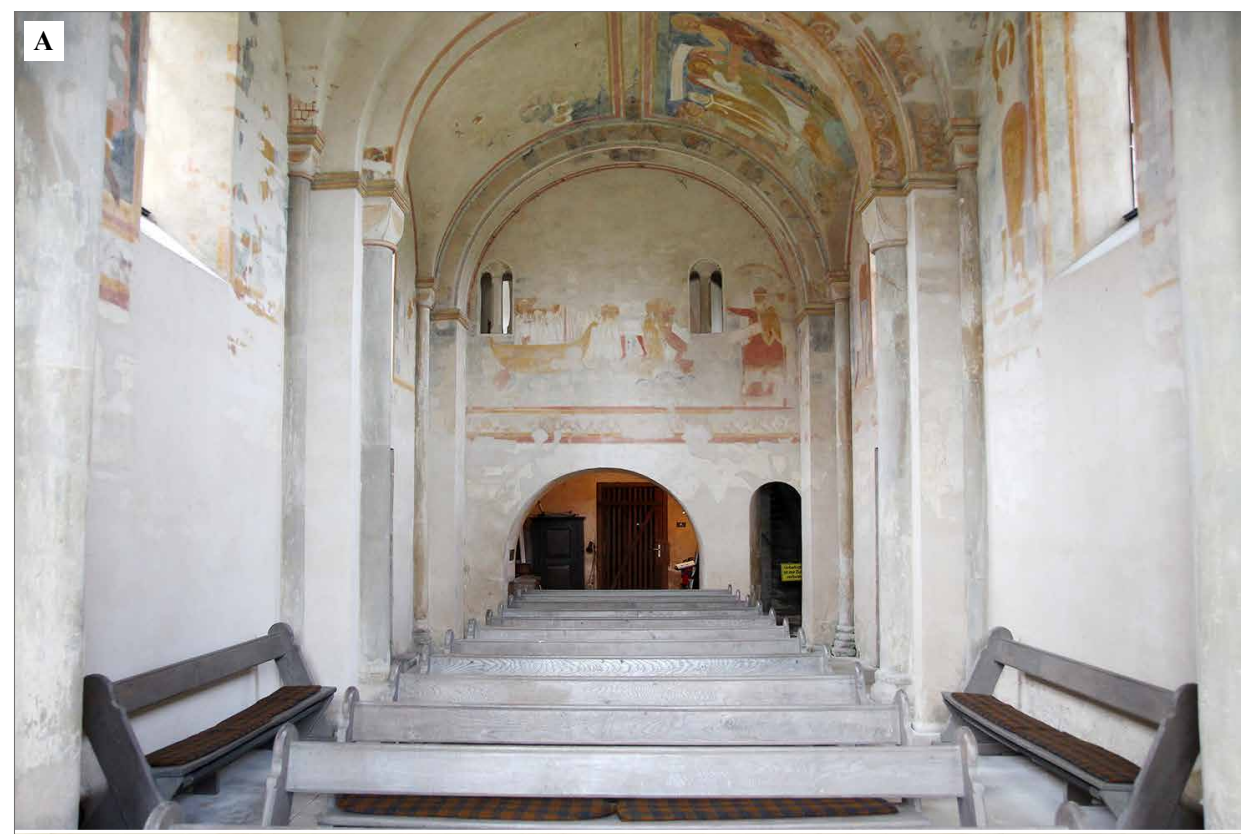

B
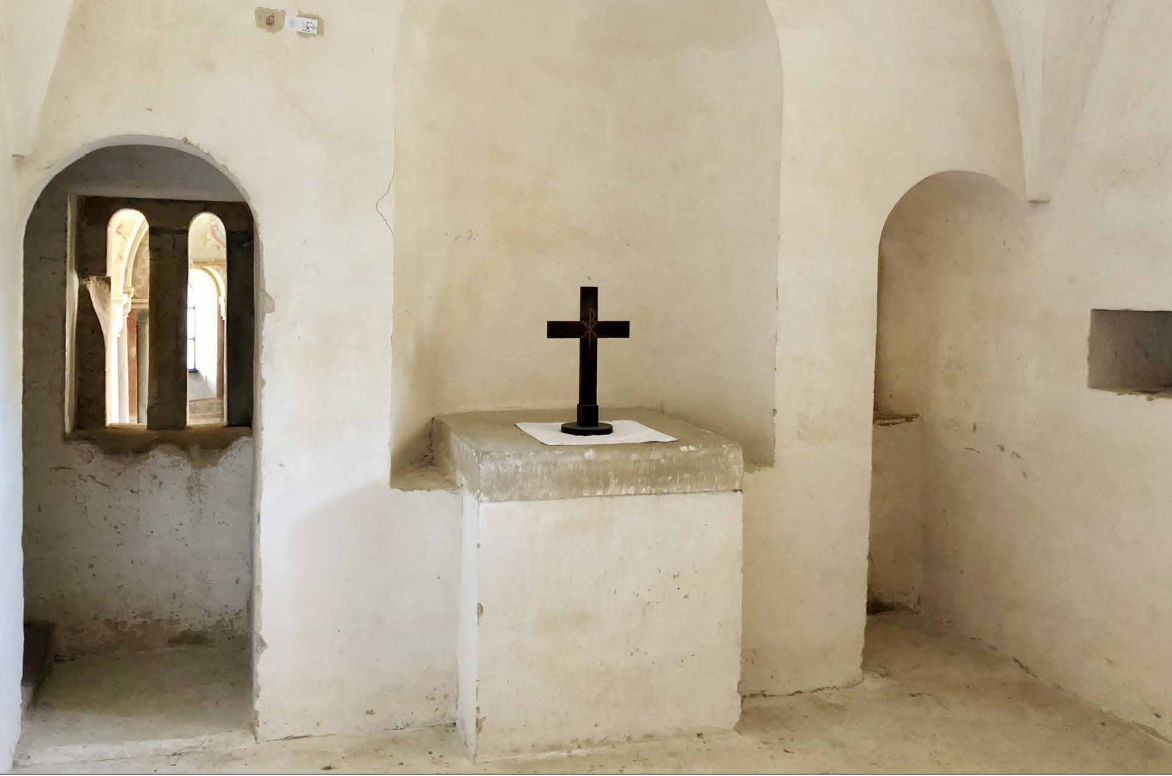

Obr. 5. Soukromá kaple mindenského biskupa Sigwarda v prvním patře věže jeho kostela v Idensen (Dolní Sasko, Německo) z konce 2. desetiletí 12. století. A - pohled z lodi kostela západním směrem, sdružená okénka v patře věže umožňují vizuální spojení kaple s oltářem (zdroj Wikimedia commons); B - interiér kaple (foto Monika Andrae, Freundeskreis Sigwardskirche).

Abb. 5. Privatkapelle des Mindener Bischofs Sigward im ersten Stock des Turms seiner Kirche in Idensen (Niedersachsen, Deutschland) vom Ende des 2. Jahrzehnts des 12. Jhdts. A - Blick vom Kirchenschiff nach Westen, die Zwillingsfenster im ersten Stock des Turms ermöglichen eine visuelle Verbindung der Kapelle mit dem Altar (Quelle Wikimedia commons); B - Innenraum der Kapelle (Foto Monika Andrae, Freundeskreis Sigwardskirche). 
kláštera Panny Marie na kolínském Kapitolu. Zdejší kostel náležel ke dvorci, který sloužil jako jedna z hospodářských základen tohoto kláštera (Holzinger 1962, 63 a 67).

Z románské fáze kostela sv. Jana Křtitele v Kleinbüllesheimu se dochovala pouze věž s kaplí v patře, která rozvrhem východní stěny se střední oltářní nikou, pozůstatkem sdruženého okénka vlevo od ní a vstupním portálkem vpravo rovněž blízce připomíná kapli Sigwardovu. Řešení vertikální komunikace však zůstalo, podobně jako ve Wollersheimu, méně stavebně náročné. Staré osídlení s dvorem a kaplí náleželo již od roku 1052 kapitule při kolínském dómu. Datování stavebních etap kostela zkomplikovala puristická úprava kostela ze sklonku 19. století. Podle analogie stavebních detailů se o dolní časové hranici výstavby věže uvažuje nejdříve v polovině 11. století (Holzinger 1962, 23-33).

Románský kostel sv. Michaela v Niederzündorfu (obr. 6A, B) vznikl v rušném překladišti zboží na rýnském břehu v předpolí Kolína. $\mathrm{V}$ době první zmínky o předchůdci nynějšího kostela v roce 1108 již většinu zdejšího území drželo benediktinské opatství v Deutz. V tomto roce věnovala polovinu zdejšího kostela jeho urozená majitelka témuž klášteru. Z mladší románské stavby, která tento původní kostel vystřídala, se zachovala západní věž s tribunou v prvním patře. Její interiér se do prostoru lodi otevíral dvojicí podvojných okének se středními sloupky.

Klášter v Deutz získal po polovině 11. století také část sousední vsi Oberzündorf (obr. 7A, B). Nejstarší část zdejšího kostela sv. Martina představuje věž s tribunou v prvním patře otevřenou do zčásti zachované lodi půlkruhovým obloukem. V interiéru tribuny jsou patrné pozůstatky původního oltáře. Blíže nezkoumanou stavbu literatura rámcově klade do druhé poloviny 12. století, stejně jako kostel sv. Michaela v sousedním Niederzündorfu. Písemné prameny zmiňují přítomnost dvou kněží k roku 1155. Věžní část tribuny kostela v Oberzündorfu byla př́stupná $\mathrm{z}$ lodi kostela schodištěm přiloženým $\mathrm{k}$ vnitřní straně její podélné zdi. Tento způsob propojení věžní tribuny s lodí připomíná komunikační vztahy, které u nás známe z kostelů v Miroticích a ze západočeského Dolního Jamného. V Polsku dochovanou paralelu téhož způsobu zpř́stupnění tribuny dokládají nálezy z kostela sv. Mikuláše ve Wysocicích (Tomaszewski 1974, 161-164) a sv. Markéty v Kościelci Kujawském (tamtéž, 164-168). Další příklady blízkého řešení věžních tribun ze švédských kostelů ve Vä, Lyngsjö, Simris a Fjälkestad publikoval K. Hansen (2013).

Věžní tribuny z venkovských kostelů zázemí středověkého Kolína nad Rýnem zjednodušeným způsobem uplatňují motiv západních věží s tribunami a kaplemi v patře, který se v rozvinuté formě uplatnil ve velkých kolínských dómech. Potenciál dalších zjištění naznačuje starší práce G. W. Holzingera, který na vybraném území jižně od Kolína identifikoval řadu dalších př́íkladů. Na území děkanátů Jülich, Bergheim, Neuss, Deutz, Siegburg, Ahrgau a Zülpich eviduje 41 románských kostelů se západními věžemi, které obsahují pozůstatky kaplí.

Spřízněnost zjevu, měřítka i blízkost vnitřního uspořádání s tribunovými kostely známými ze středoevropského prostoru dokládá kostel sv. Anny v Auderghemu (obr. 9) jihovýchodně od Bruselu. Kostel, o němž se předpokládá, že byl součástí dvorce, se datuje s rozpaky vyplývajícími z prostého výrazu a absence zdobného detailu do širokého rozpětí mezi 11. a počátkem 13. století. Z historických zmínek, které se vztahují k vlastnickým poměrům v území, lze snad tento interval zúžit na období mezi koncem 11. a polovinou 12. století (Charruadas-Layeux 2014). Zaniklou pavlačovou tribunu v západní části lodi prozrazuje v odpovídající výši dochovaný portálek, který spojuje patro věže s lodí. Přízemí i patro věže jsou klenuté. Přístup do jejích vyšších pater umožňoval portálek ve třetím věžním patře otevřený do lodi. Dostat se $\mathrm{k}$ němu dalo žebříkem z tribuny. Stejný komunikační systém byl rekonstruován v posázavských Chřenovicích (nepublikovaný výzkum autorky a M. Falty). Mimořádně úsporná a drobná kaple sv. Anny v současnosti představuje mezi dochovanými belgickými venkovskými kostely již jen výjimku. Přesto lze u řady dalších kostelů v Brabantsku a přilehlých územích existenci obdobných jednolodních kostelů se západními věžemi předpokládat. Běžným typem venkovského románského kostela v tomto regionu je obvykle trojlodní bazilika se západní věží. Věže bývají starší. Do mladší středověké stavby byly pojaty jako nadále užitečná součást zbořeného předchůdce. Díky velké dynamice 


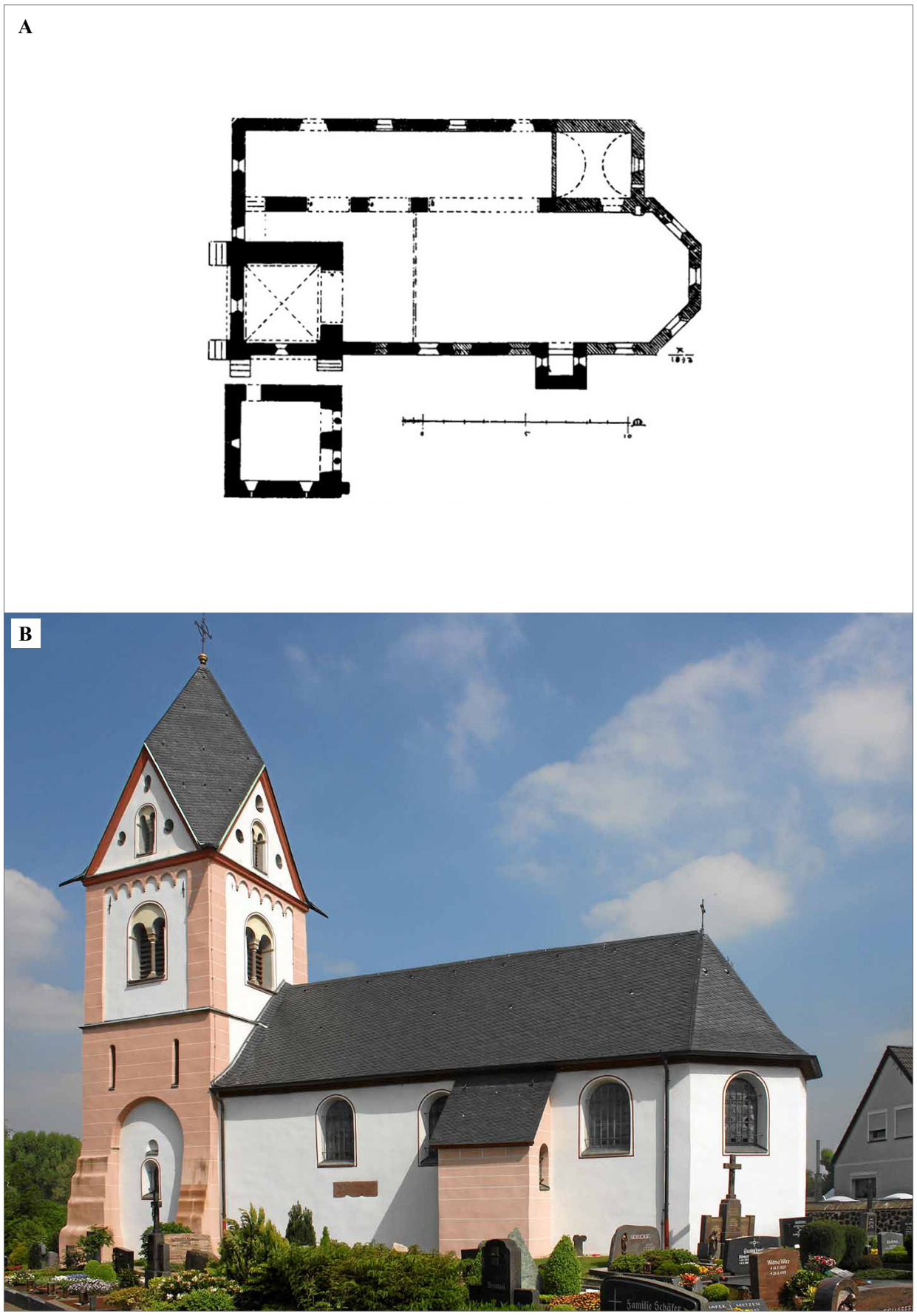

Obr. 6. Kostel sv. Michaela v Niederzündorfu (Köln-Zündorf, Severní Porýní-Vestfálsko, Německo). A - půdorys na úrovni přízemí s detailem půdorysu patra věže s věžní tribunou a přístupem z vnějšku stavby od severu, lod' je výsledkem mladších přestaveb (podle Clemen 1900, 115); B - pohled od jihu (zdroj Wikimedia commons).

Abb. 6. Michaeliskirche in Niederzündorf (Köln-Zündorf, Nordrhein Westfalen, Deutschland). A - Grundriss auf Erdgeschossniveau mit Grundrissdetail des ersten Stocks des Turms mit Turmempore und Zugang von außen von Norden, das Schiff ist das Ergebnis jüngerer Umbauten (nach Clemen 1900, 115); B - Blick von Süden (Quelle Wikimedia commons). 

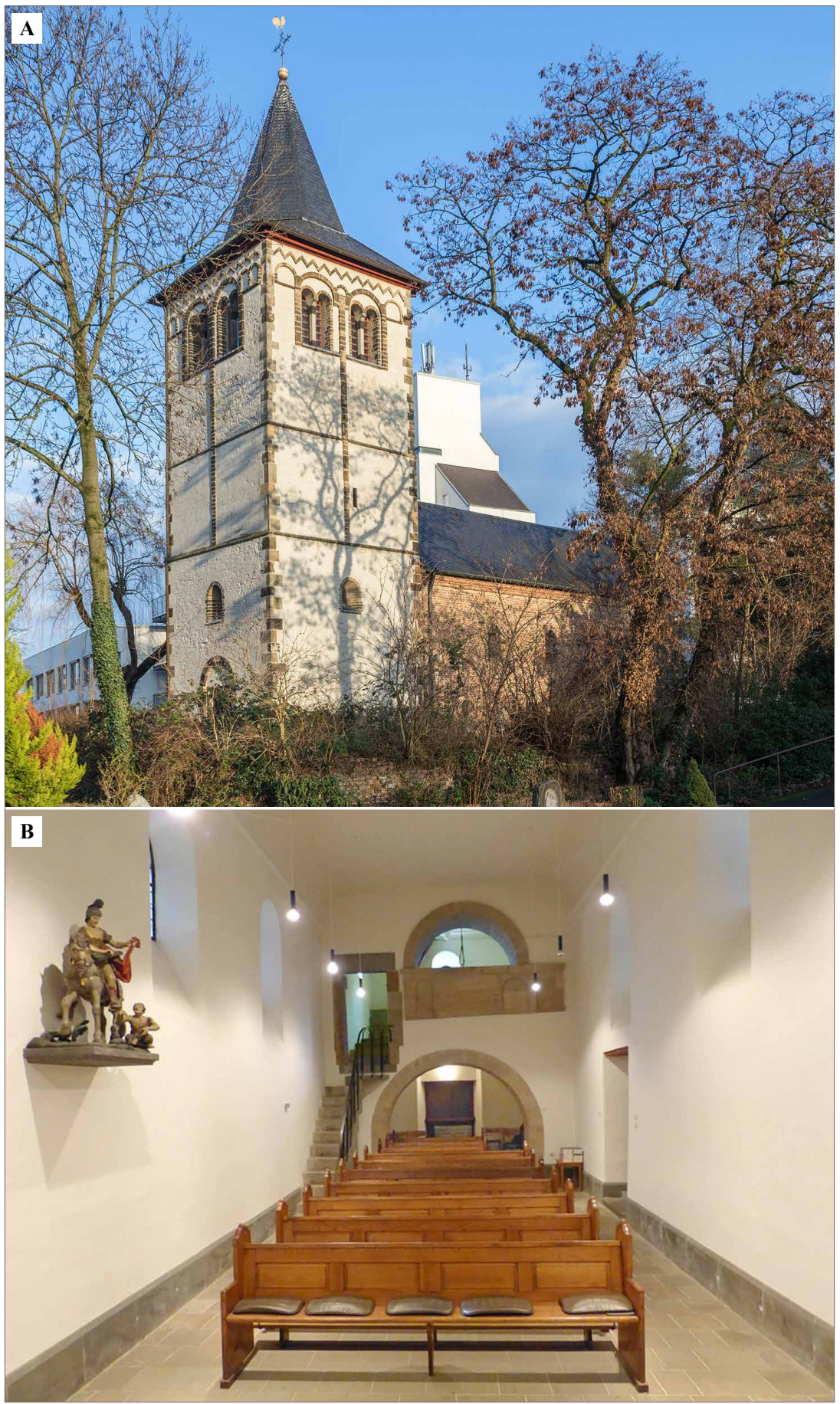

Obr. 7. Kostel sv. Martina v Ober Zündorfu (Köln-Zündorf, Severní Porýní-Vestfálsko, Německo). A - pohled od severovýchodu; B - prủhled lodí směrem k západní tribuně v patře věže. Foto Celia Körber-Leupold, Köln.

Abb. 7. St. Martinuskirche in Oberzündorf (Köln-Zündorf, Nordrhein Westfalen, Deutschland). A - Blick von Nordost; B - Durchblick in Richtung Westempore im 1. Stock des Turms. Foto Celia Körber-Leupold, Köln. 


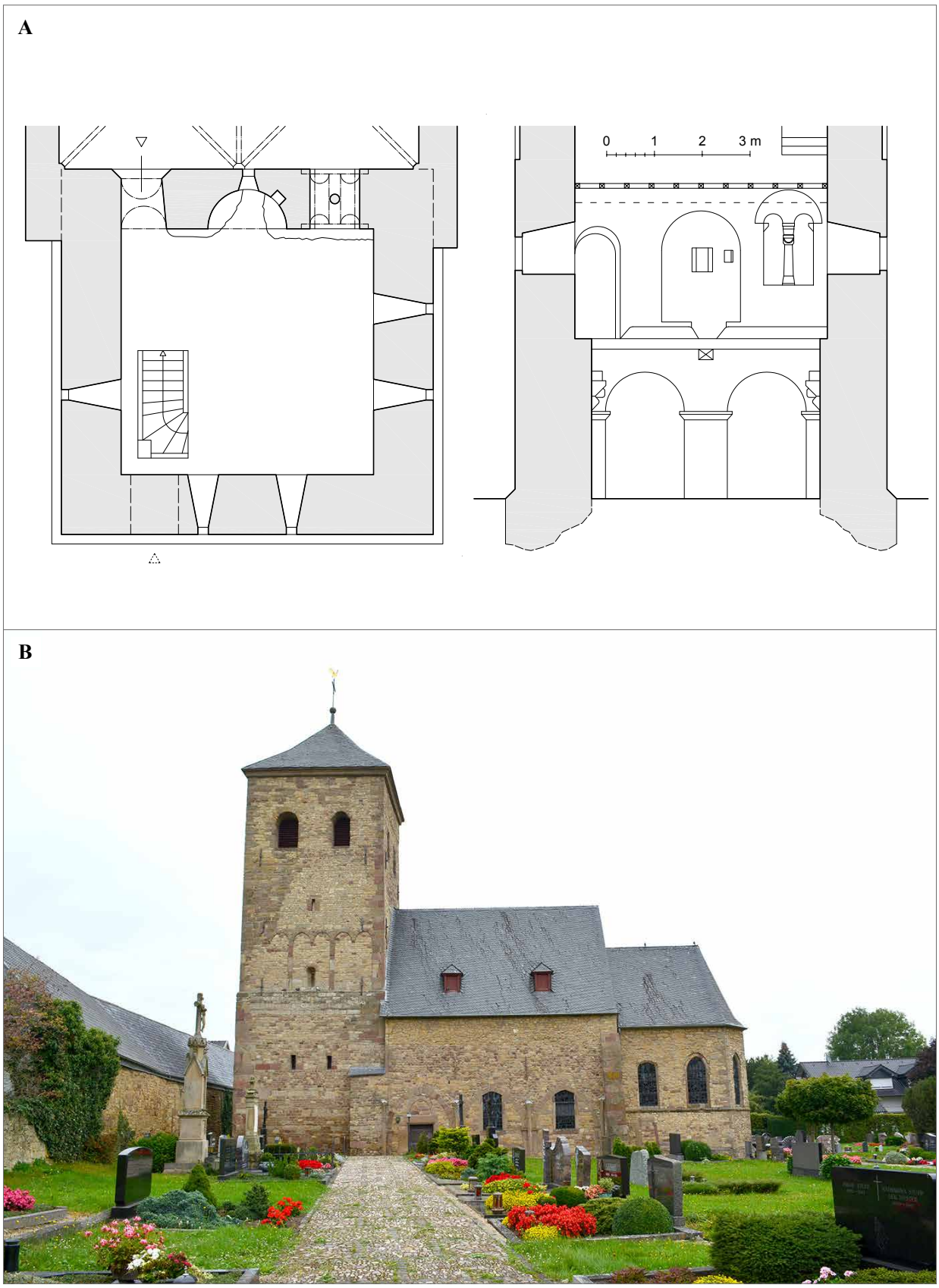

Obr. 8. Západní věž ve Wollersheimu (Nideggen-Wollersheim, Severní Porýní-Vestfálsko, Německo). A - řez věží s pohledem na její východní stěnu v patře s oltářem a prủzorem do lodi (podle Holtzinger 1962, upraveno, kresba M. Falta); B - celkový pohled na zástupce početněji dochované skupiny románských kostelů s kaplí v patře věže, původní lod' kostela byla nahrazena pozdněgotickou novostavbou (zdroj Wikimedia commons).

Abb. 8. Westturm in Wollersheim (Nideggen-Wollersheim, Nordrhein Westfalen, Deutschland). A - Schnittdarstellung des Turms mit Blick auf seine Ostwand im 1. Stock mit Altar und Guckfensterchen ins Schiff (nach Holtzinger 1962, Bearbeitung, Zeichnung M. Falta); B - Gesamtansicht des Vertreters einer zahlreicher erhalten gebliebenen Gruppe romanischer Kirchen mit Kapelle im 1. Stock des Turms, das ursprüngliche Kirchenschiff wurde durch einen spätgotischen Neubau ersetzt (Quelle Wikimedia commons). 


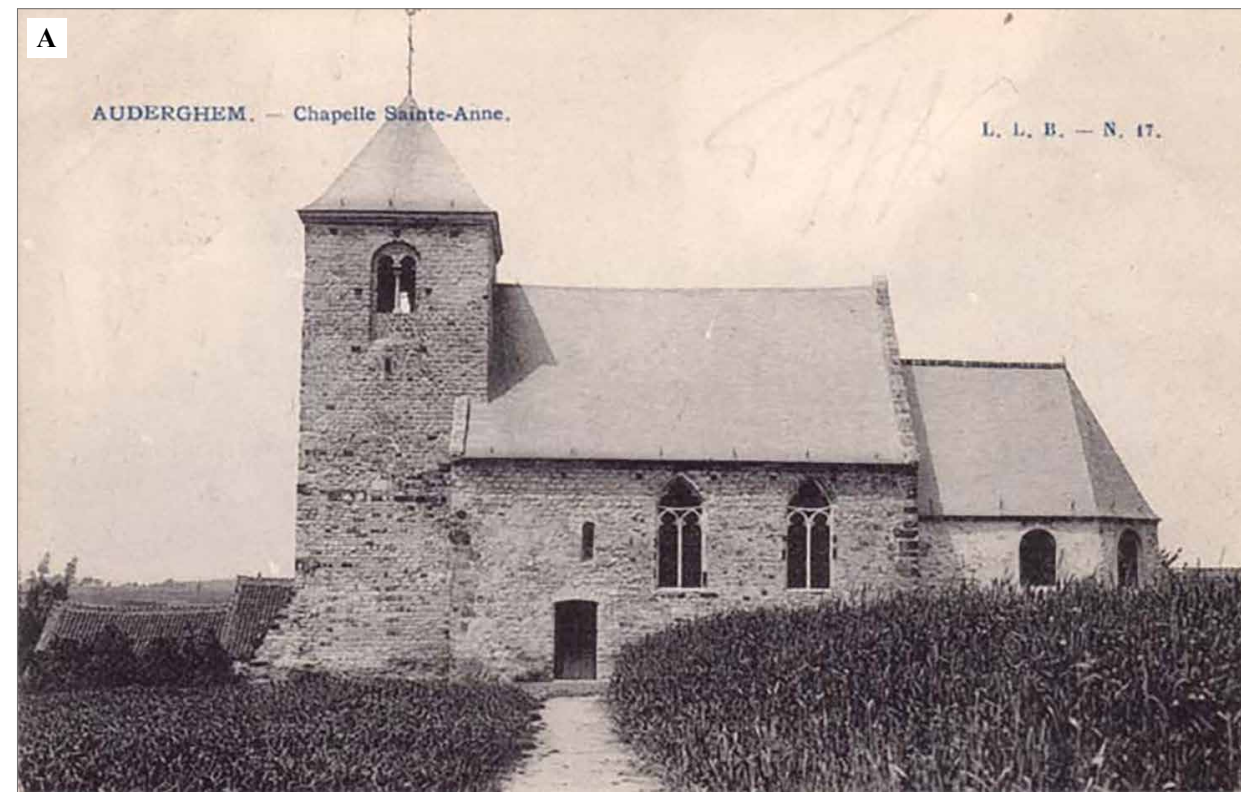

$\mathbf{B}$

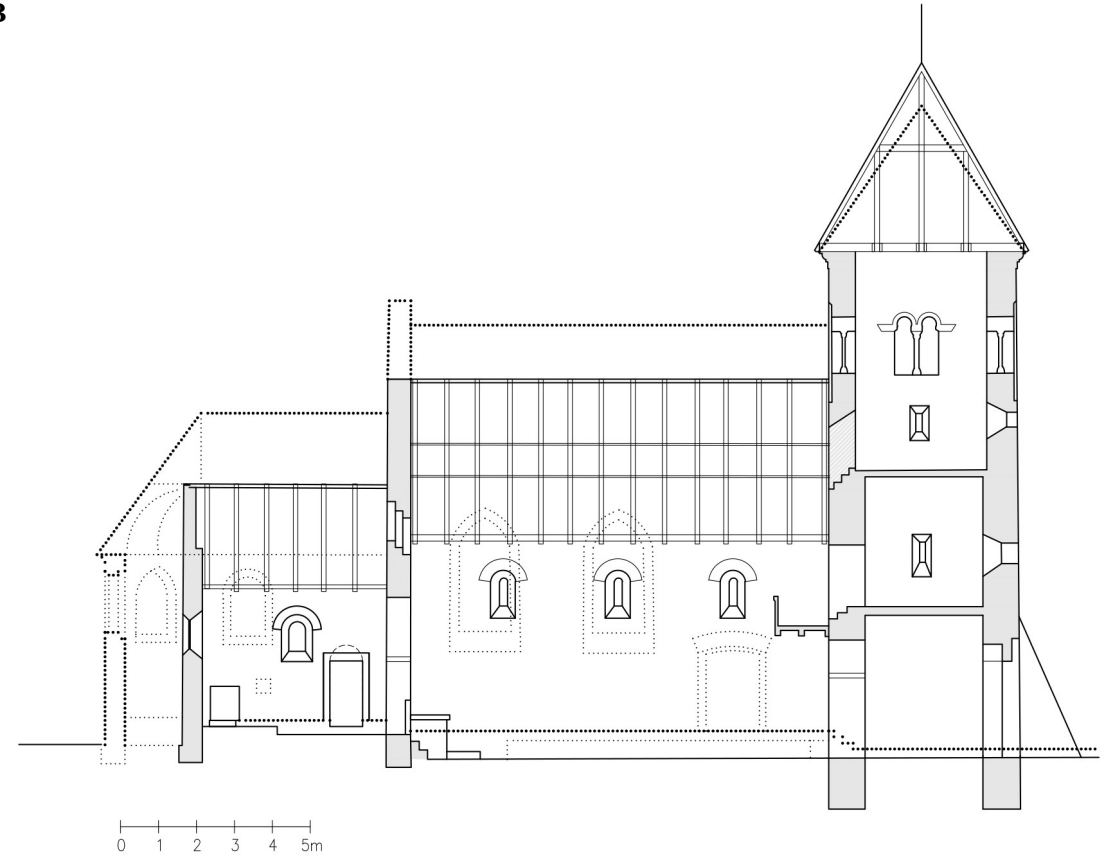

Obr. 9. Kostel sv. Anny, Auderghem (Bruxelles-Capitale, Val-Duchese, Belgie). Vzácně dochovaný příklad z dř́ive početnějšího souboru drobných románských jednolodních kostelů se západní věží. A - pohled od jihu před restaurací v roce 1915 (archiv autorky); B - podélný řez kostelem s pohledem na jižní stěnu kostela, tečkovaně vyznačen stav před reromanizací (podle originálních plánů R. Lemaire z roku 1915, upraveno, kresba M. Biedermannová).

Abb. 9. Annenkirche, Auderghem (Brüssel-Hauptstadt, Val-Duchesse, Belgien). Seltenes erhalten gebliebenes Beispiel aus der früher zahlreicheren Gruppe kleiner romanischer einschiffiger Kirchen mit Westturm. A - Blick von Süden vor der Restaurierung von 1915 (Archiv der Verfasserin); B - Längsschnitt der Kirche mit Blick auf die Kirchensüdwand, Zustand vor der Reromanisierung punktiert gekennzeichnet (nach Originalplänen von R. Lemaire von 1915, Bearbeitung, Zeichnung M. Biedermannová). 
hospodářského rozvoje tohoto území ve středověku došlo k popsané náhradě většiny drobných venkovských kostelíků bazilikami velmi záhy. Často již v ranějším středověku (obr. 10).

Není cílem tohoto textu poskytnout dosud chybějící přehled jednolodních venkovských tribunových kostelů se západní věží mimo území jejich u nás známého výskytu. Současné poznatky zatím také takový pohled neumožňují. Nerozvíjí se zde ani další samostatná linie, která by mohla být vedena od velkých vzorů z benediktinského prostředí, kde mělo západní jednověží své zvláštní významové opodstatnění. Následovaným prríkladem se stal mohutný západní útvar klášterního kostela v Cluny z první poloviny 11. století s kryptou, která byla určena jako pohřební místo významných osobností podporujících klášter (Krüger 2003; 2003a), nebo obrovitá západní věž v Saint-Benoît-sur-Loire (obr. 11). Záměr, který překvapuje již rozměrem a masivností dochované spodní části stavby, dává tušit zamýšlené dimenze západní zvonové věže. Dílo, které po smrti svého ambiciózního stavebníka opata Gauzlina v roce 1030 ztratilo podporu, nicméně provází výslovně doložené přání stavebníka, aby se věž jeho kostela „stala přikladem pro celou Galii“ (Vergnolle 1985, 277). Věž byla snížena v 16. století nejspíše o dvě patra. Na francouzské západní věže tohoto typu s průchozím prrízemkem (clocher-porche) rovněž navázala řada odvozenin. Mimo záběr textu zůstávají rovněž západní románská jednověží jak čtyřúhelníkového, tak kruhového půdorysu v Anglii a Skandinávii.

Zvolené př́íklady nás však zavádějí do oblastí, v nichž dosažené stadium vývoje feudálního sídla zjevně neopodstatňovalo potřebu pomocí kostelní věže předjímat či nahrazovat chybějící vertikálu věže hradní. Věž kostela a věž hradu zde představovaly autonomní stavební úkoly, které spojovaly právě jen některé velmi obecné roviny jejich symbolické i praktické funkce. Malé jednolodní kostely se západními věžemi vybavenými tribunami zjištěné v Porýní představují samostatný typologický druh sakrální stavby, která se vyskytuje ve vazbě na venkovský statek velkého feudála, jeho leníků nebo správců. Cesty napodobení těchto vzorů se přitom mohly ubírat jak citacemi vizuálních znaků, tak i návazností na jejich funkční a významové charakteristiky. Stavba je velmi komplexním dílem. $\mathrm{K}$ jeho uskutečnění i případnému napodobení je třeba nejen představa o vzhledu, ale i znalost, dovednost, zkušenost a organizační i technické zázemí. O době, v níž se naše úvahy pohybují, se na základě dobových zmínek soudí, že se stavby prováděly bez předem vyhotovených plánů (Binding 2002,73-99). Vodítkem bylo prání stavebníka, které se v doložených príípadech výslovně zakládalo na požadavku podobnosti zamýšlené stavby s určeným vzorem (Binding-Linscheid-Burdich 2002, 67). Takové př́ní stavebníka z roku 1132 ukládá vystavět skromnou svatyni v Gross-Frankenthal podle vzoru (,,ad exemplum“) kostela sv. Amanda ve Wormsu. Farní kostel sv. Amanda zanikl na přelomu 18. a 19. století. Z dobových plánů je z románského stadia výstavby identifikovatelná jen věž se sdruženými okny (Kranzbühler 1905, 7-15). Vzácně doložený př́ípad záměrné nápodoby tak nelze stvrdit fyzickou podobou obou staveb. Dobové texty dokládají, že nositelem i zprostředkovatelem představy o stavebním díle byl provádějící mistr sám, který stavbu bezprostředně řídil svými konkrétními př́kazy (,opus in mente conceptum“ - tamtéž, 151). Stavbu vedl zkušený stavitel $\mathrm{s}$ jasnou představou výsledku, kterou se svými pomocníky bezprostředně uskutečňoval. Fyzická prítomnost mistra byla nezastupitelná. Jeho zranění nebo smrt ohrožovaly dokončení díla. Pohyb takových stavitelů po staveništích raně středověké Evropy není vzhledem k mezerovitosti pramenné základny snadné mapovat. Výzdoba některých románských kostelů nebo užité stavební způsoby však v některých případech dovolují zapojit stavby dochované na území našeho státu do sítí šiřrení stavebních projevů se stejnými nebo blízkými charakteristickými znaky. Roli takového, i když méně ostře vyhraněného znaku než detaily výzdobných motivů (Benešovská 2010, 235-237 a 240) a způsob jejich uplatnění mají i dispoziční rozvrh stavby a komunikační vztahy, které dispozice umožňuje. Věžní tribuny uvedených porýnských kostelů mají tatáž nebo velmi blízká architektonická řešení, dispoziční uspořádání i komunikační vazby, které byly zatím zjištěny u skupiny románských tribunových kostelů se západními věžemi ve středovýchodní a severní Evropě. Podobné rysy můžeme najít u kostelů v Miroticích, Dolním Jamném, Wysocicích a Kościelci Kujawském v Polsku (Tomaszewski 1974, 161-168) a ve Vä, Lyngsjö a Simris ve Švédsku (Hansen 2013, 198-191). Výzkum bližších podrobností této korelace je však v zatím na samém počátku. 

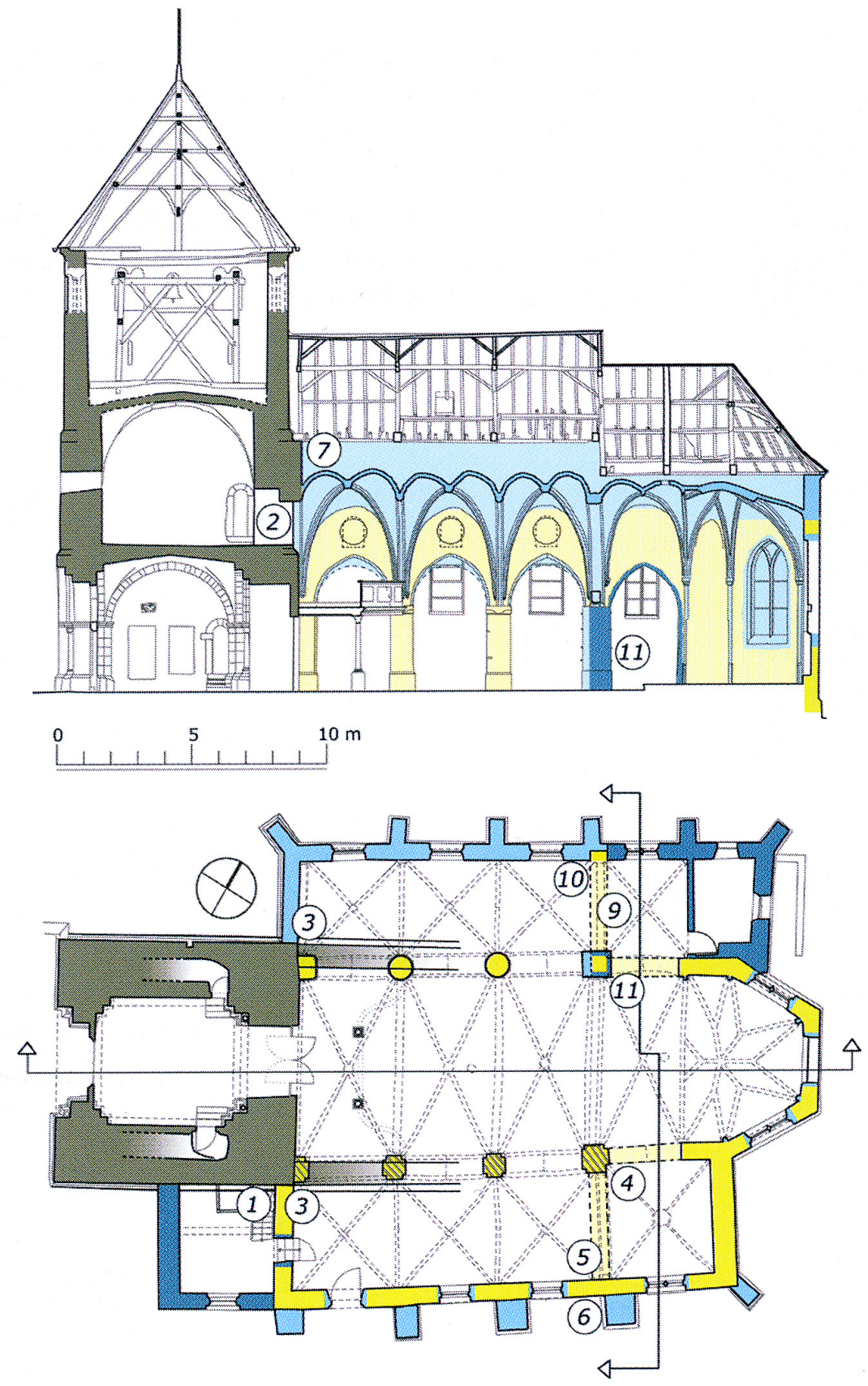

Obr. 10. Současný stavebněhistorický průzkum zjišt'uje jednolodní předchůdce u kostelů s mladšími loděmi přiloženými k románským věžím s tribunami. Kostel. sv. Martina, Jülich-Barmen (Severní Porýní-Vestfálsko, Německo), půdorys a řez. Podle Dudzinski 2019, 75.

Abb. 10. Eine heutige bauhistorische Untersuchung stellt eine einschiffige Vorgängerin mit an den mit Emporen versehenen romanischen Türmen anligenden jüngeren Schiffen fest. St. Martinus, Jülich-Barmen (Nordrhein Westfalen, Deutschland), Grundriss und Schnitt. Nach Dudzinski 2019, 75. 


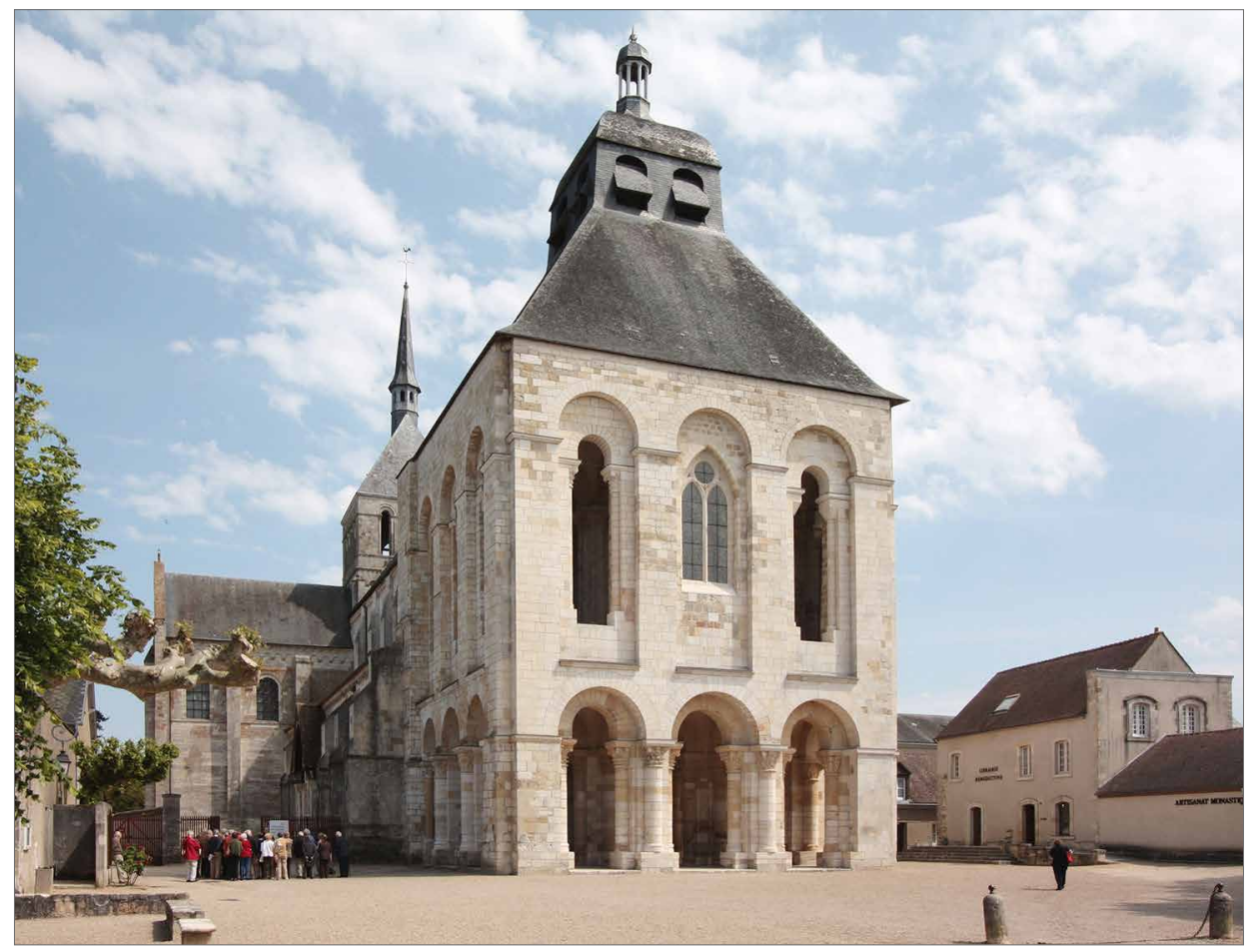

Obr. 11. Nedostavěná západní věž klášterního kostela Fleury v Saint-Benoît-sur-Loire (Centre-Val de Loire, Francie), před 1030. Zdroj Wikimedia commons.

Abb. 11. Nicht fertiggestellter Westturm der Klosterkirche Fleury in Saint-Benoît-sur-Loire (Centre-Val de Loire, Frankreich), vor 1030. Quelle Wikimedia commons.

\section{K symbolice kostelní věže}

Věž vždy představovala mimořádně působivý stavební počin. Přičítala se jí řada významů, které přesahovaly její praktickou funkci. Již před příchodem křestanství nabyla významu složitého symbolu, který spolu s obrazem města opevněného hradbami a věžemi později našel uplatnění v symbolické řeči křest’anského umění.

Věž není sice s kostelem spjata od začátků křest’anství, ale stala se jeho součástí daleko dřív, než se v prostoru středovýchodní Evropy začaly stavět kostely. V době, v níž Lavalův článek navrhuje hledat na východním okraji latinského světa stopy geneze kostela se západní věží, se již po několik staletí do výtvarných a stavebních zadání latinské církve propisovala řeč jejích vlastních symbolů. Sblížení s tímto duchovním světem představovalo nedílnou součást procesu christianizace středovýchodní Evropy.

Na ideálním plánu kláštera ze St. Gallen jsou u klášterního chrámu zakresleny dvě západní věže se symbolickým a liturgickým posláním - jsou zasvěceny archandělům sv. Michaelovi a Gabrielovi. První patra obou věží byla určena kaplím s oltáři těchto andělských ochránců. Poznatky o souvislostech svatomichalského kultu a jeho spojení se západními partiemi kostelů shrnul na základě zejména německé a mad’arské literatury P. Tajkov (2010). Vazba kostela a zvonice byla vnímána jak v rovině teologické, tak církevní. Honorius Augustodunensis (1080-1154) mluví o zvonici v souvislosti s hlasitým kázáním z nebes a symbolicky vysvětluje i počet kostelních věží (dvě přikázání, podobně i Siccard Cremonský /1155-1215/). Ustálilo se chápání funkce věže jako zvonice. V roce 965 byla zasažena bleskem zvonice opatství St. Pierre v Tournus. Mnich 
Vilhelm, který o události podal zprávu, ji označil výslovně jako „turris signorum“ (Courtépée 1779, 478-489) a připojil další označení zvonice: cloccarium (,... Quam rustici clocarium dicimus.“). Od 10. století jsou doložena také zakončení hrotů věží v podobě kohouta jako symbolu Kristova, který značí vítězství nad zlými silami tmy a volání po světlém dni. Symbolika kohouta se odráží v označení Gallicinium pro dobu ranní modlitby - matutinum, k němuž jsou buzeni spáči. ${ }^{1}$ Tyto skutečnosti dokládají uvědomělé spojení věže s duchovní symbolikou kostela a jeho náboženskou funkcí.

Není však pochyb, že symbolika věže mohla v různých kulturních kontextech různě rezonovat. Duchovní významy přičítané věži ovšem nevytěsnily obecnější významovou rovinu. Věž v očích současníků zjednávala chrámové stavbě majestát a dojem výpravnosti a okázalosti. Generální kapitula cisterciáků roku 1157 ve snaze o skromnost a prostotu výrazu rádové architektury proto zakázala spolu s dalšími projevy nadbytečné zdobnosti výstavbu zděných zvonic. Nařízení rádové kapituly z roku 1157 požaduje: „Turres lapidee ad campanas non fiant“ (Canivez 1933, 61, č. 16). Vlastně totéž ŕíkají narbonnská ustanovení minoritů: „Campanile ecclesiae ad modum turris de cetero nusquam fiant." ${ }^{\text {2 }}$ Právě v důrazu tohoto zákazu se obráží síla symbolického významu, který věž v očích svých současníků měla. Ovšem zároveň je zcela evidentní, že věž jako symbol v tomto kontextu budí představu neprŕípustné nádhery a výstavnosti. Zákaz vznik1 v intelektuálním prostředí francouzského řeholního kléru a do jeho řad i cílil. Záměr usměrnit použití architektonických forem se symbolickým obsahem na vnějšku kostela však naznačuje, že jejich srozumitelnost i mimo řeholní společenství nebyla bez významu

Autentickým dokladem představ, které mohla vyvolávat mohutnost a zřejmá nedobytnost zděné kostelní věže, je způsob, jímž byla v druhém desetiletí 12. století popisována věž klášterního kostela v St. Trond (Belgie): „Pretera Turris monasterii firmissima quasi arx excelsa (...) et plenos securitatis prebens illis qui in turre morabantur recessus“" (Binding 2002, 612). Návaznost prostorové struktury kostela na karolínské vzory je zřejmá. Přirovnání k pevnosti a možnost úkrytu, kterou věž bezesporu skýtala, však neznamenají, že by tato stavba byla odvozena od soudobé hradní architektury a že by její pevnostní vzhled měl v očích současníků potlačovat její sakrální význam. Pro tuto úvahu je podstatné, že architektonická forma nepůsobí jako jednoznačně čitelný znak se závazným výkladem, ale jako symbol. Do způsobu, jakým se rozumí symbolu, se vždy zásadně promítá situace jeho příjemce, jeho výchozí znalosti a očekávání a kulturní rámec, $\mathrm{v}$ němž $\mathrm{k}$ této interakci dochází. Různé významové polohy symbolu mohou být dokonce vnímány současně, aniž se vzájemně vylučují.

V situacích, kdy zděný kostel představoval jedinou skutečně bezpečnou stavbu, nabývaly přirozeně na důležitosti fyzické kvality útočiště, které nabízel. Nelze však z toho prŕímo dovozovat, že by proto ustupovalo do pozadí povědomí o jeho sakrální funkci a představa symbolické duchovní pevnosti, které byly s kostelem spojeny. I když reálná stavba kostela - ecclesia materialis - plnila př́ležitostně nejrůznější praktické funkce, vždy zároveň byla projevem ecclesie spiritualis, kterou v reálném světě středověkého křest’ana viditelně zpřítomňovala.

\section{K otázce časové posloupnosti nástupu věží v sakrálním prostředí a u sídel elit}

V západní Evropě lze v průběhu 11. a 12. století pozorovat nápadný vzestup četnosti nově budovaných věží u církevních i světských staveb. S věžemi se v hojnější míře než dříve počítalo v konceptu novostaveb. Přistavovaly se také často ke starším bezvěžovým stavbám. Zvyšovaly se a upravovaly věže staré. Úměrně stavu dochovaných pozůstatků můžeme počátek této proměny zaznamenat v době, kdy se sídla urozených v Normandii, Anjou a v Porýní vyvazují z předchozího sepětí se zemědělským osídlením a usazují se „vysoko a daleko“ od něho. Později se zájem o zdůraznění významu rodového sídla prosazuje i v městském prostředí, kde žene patricijské

1 Za upozornění děkuji prof. Petru Sommerovi.

2 Za upozornění děkuji prof. Petru Sommerovi. 
rody do soupeření o dosaženou výšku palácových věží. Věže městských paláců měly vedle praktického nepominutelný symbolický, oslavný a reprezentační význam, stejně jako sídla nobility na venkově. Specializace směrů současného studia dějin stavební kultury může vést k tomu, že tento proces sledovaný v typologickém okruhu sídel vyšších společenských vrstev není konfrontován s paralelními projevy v prostředí staveb sakrálních. Nicméně srovnání zároveň ukazuje, že známé doklady zvýrazňování významných stavebních podniků věží jsou u sakrálních staveb starší než u sídel nobility. Stav dochování dokladů starších vrstev stavební kultury však nedovoluje snadno soudit, zda známé kostelní věže z těchto ranějších období a písemné zmínky o nich dokládají spíše vzácné jevy, nebo jen náhodně dochované doklady dřive rozšířenějšího jevu.

Jednotlivá věž nebo jejich různé sestavy zvýrazňovaly navenek nejdůležitější části stavby a dávaly najevo její význam a důstojnost. Prameny dokládají, že odlesk mimořádnosti takových stavebních podniků, které budování věží představovalo, dopadal i na samého donátora. Věže jako významný prvek obnoveného klášterního komplexu v Centule uvádí opat Angilbert na sklonku 8. století (Horáčková 2014, s. 44). Podle Hariulfa, autora kroniky opatství v St-Riquier, byly po obvodu stěn východní věže zasvěcené svatému Richariovi a západní věže věnované Spasiteli vytesány verše. Tlumočí hrdé uspokojení opata Angilberta nádherným dílem, které bude s jeho osobou i s podporou císaře Karla Velikého již natrvalo spojováno. V tomto kontextu lze chápat i výjimečnou epigrafickou památku z českého prostředí - nápis z věže románského kostela sv. Petra a Pavla v Lenešicích u Loun, který uvádí jako stavebníka věže opata postoloprtského kláštera Bertolda. Hodnostář svatovítské kapituly děkan Vít nechal někdy ve druhé třetině 13. století ve Sluhách „kostel znova od základư vystavět jako stavbu velmi vznešenou a vyzdvihl nad ním velmi krásnou věž $k$ oslavě svatého Vojtěcha mučedníka“ (Klápště 2005, 83; FRB II, 325; Žemlička 1998). V 11. a 12. století se obliba věží i technická dovednost budovat je vrcholným způsobem naplnily v kompozicích, jakými jsou dómy ve Špýru, v Mohuči, opatství Maria Laach nebo katedrála v Tournai (obr. 12). Vlna budování věží u monumentálních sakrálních staveb se přirozeně promítla i do podoby drobných kostelů s různě umístěnými věžemi.

\section{Etapizace výstavby kostela a její projevy}

Přes význam, který byl věži přikládán, ji zdaleka všechny kostely neměly. Náročnost a nákladnost odsouvala mnohdy její výstavbu do následných etap, pokud se na ni již od počátku nerezignovalo. Věže zůstávaly často nedokončeny (Hauserová a kol. 2011; viz také Falta 2011; 2013; 2014; 2014a). Různá stavební náročnost, výtvarné a další ambice i ekonomické možnosti jednotlivých stavebníků rozvrstvily stavby věží od těch úsporných až po nákladná a mistrovská díla. V řadě případů bylo nutno přikročit k etapizaci výstavby. Vedly k ní důvody provozní, technické i ekonomické. Zvláště u velkých sakrálních komplexů je třeba vzít tuto okolnost v úvahu a uvažovat o stavbě jako o procesu, který prochází řadou stadí́.

Jsou doloženy případy, kdy byla výstavba nebo přestavba staršího kostela rozdělena tak, že se kostelní průčelí s věžemi začalo stavět po dokončení presbytáře, ale před realizací chrámové lodě. Mezi oběma částmi se mohl otevírat volný prostor. Současná zjištění nevylučují, že takový postup mohl vést $\mathrm{k}$ situaci, která byla zachycena v Lorsch (Erbach-Schönberg a kol. 2011) a která vede F. Lavala $(2016,53-54)$ k hypotéze o samostatně stojící profánní stavbě - castellu před průčelím klášterního kostela. Spojení termínu castellum s volně stojící věží před západním průčelím kostela přikládá F. Laval roli závažného argumentu. Ilustruje jím proces přibližování civilní věže ke svatyni, s jeho důsledkem: přenesením názvu castellum na celek svatyně - kostela.

Pořadí jednotlivých etap výstavby líčí ve svých vzpomínkách na stavbu kostela v St. Denis opat Suger (Suger 2003, 106-107). Popisuje výstavbu západního průčelí klášterního kostela se spodní částí dvouvěží v době, kdy již bylo dokončeno proslulé nové presbyterium a východní transept, ale ještě se nepřikročilo k náhradě staré lodi a propojení obou částí lodí novou. Trojlodí bylo mezi východní část kostela a samostatně stojící westwerk vloženo až v následující etapě. Podrobný průběh výstavby doložil stavebněhistorický průzkum románského dómu ve Fritzlaru 


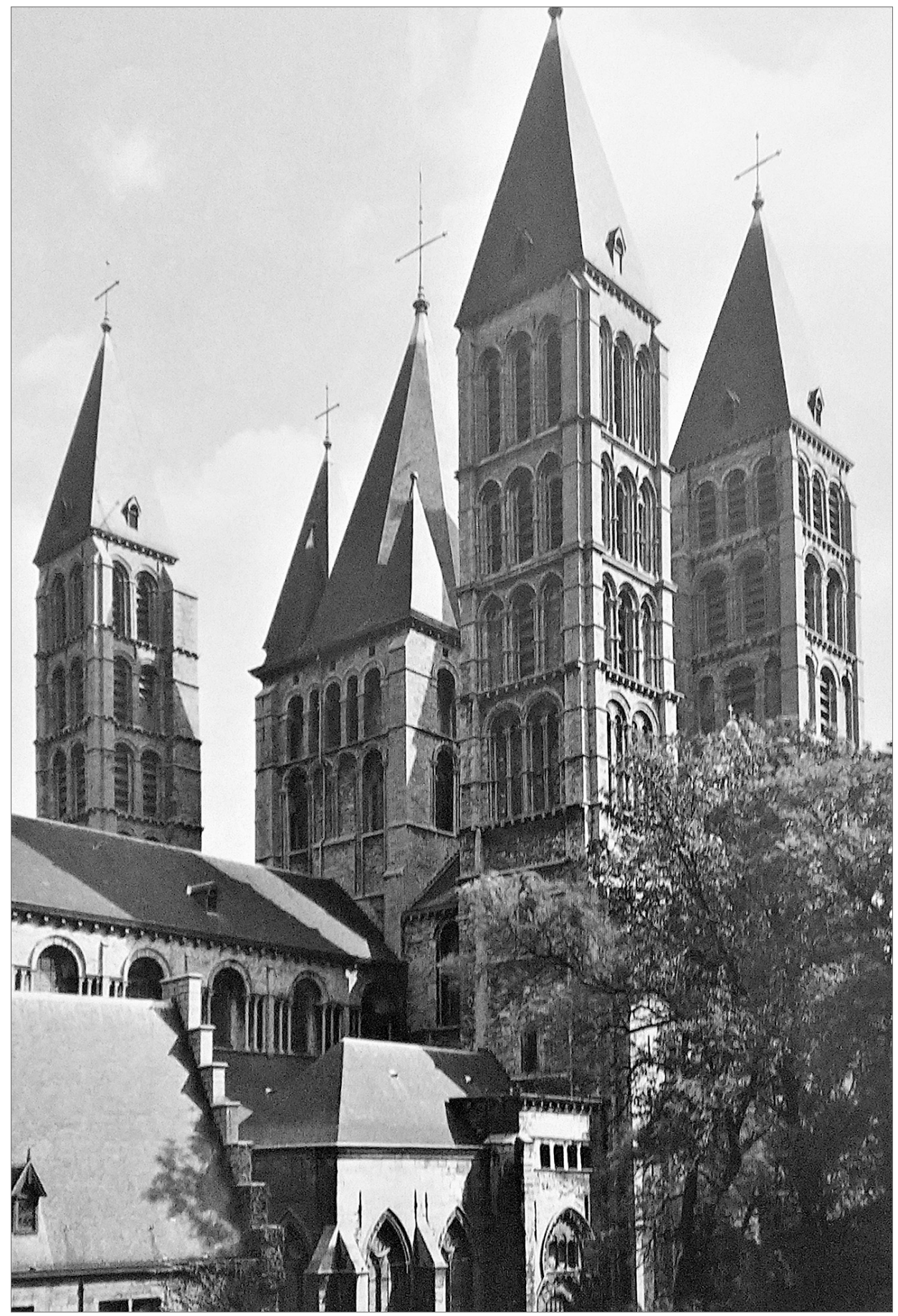

Obr. 12. Zmnožení vertikál - věže katedrály Notre-Dame v Tournai (Belgie), 2. polovina 12. století. Podle Courtens 1969, tab. XXVI.

Abb. 12. Vervielfachung der Vertikale - Türme der Kathedrale Notre-Dame von Tournai (Belgien), 2. Hälfte 12. Jhdt. Nach Courtens 1969, Taf. XXVI. 
(Humbach 2005, 218-219). Po obvyklém zahájení stavby na východě, založení krypty, východního závěru a transeptu, které tvořily první provozuschopnou část kostela, se stavba přesunula k západnímu dvouvěží. Jeho severní věž byla dovedena do výše zvonového patra. Je pravděpodobné, že v rozestavěné, ale zčásti provozuschopné stavbě již mohla plnit funkci zvonice. Jednalo by se pak o analogickou situaci ke castellu $\mathrm{v}$ Lorsch, kde byly rovněž $\mathrm{v}$ samostatně stojícím castellu doloženy zvony (signa ecclesiae). Věže se v průběhu výstavby často využívaly jako bytelná vertikální komunikace a opora zvedacích zařízení potřebných v průběhu další výstavby. Mladší analogii téhož postupu výstavby včetně umístění zvonů a zvedacího zařízení představovalo rozestavěné stadium kolínského dómu. Nové dvouvěží bylo předloženo před nedokončenou stavbu kostela i v pražském kostele P. Marie pod řetězem. V rámci této etapy vznikla i severní stěna lodi. Hmotnost západního dvouvěží nebo masivního westwerku v podobných př́padech kladla větší nároky na hloubku i způsob založení než subtilnější lod’ románského kostela, zvláště když nebyl zaklenut. Mohutná zděná základová deska byla odkryta pod západním dvouvěžím kostela sv. Alžběty v Marburku. Způsob jejího stavebního provedení ji řadí do časnější etapy výstavby než přilehlou západní část lodi (Platz 2017). Západní část lodi přiléhající k západnímu dvouvěží byla také zastřešena s odstupem dvou desetiletí až v 70. letech 13. století. Východní i západní část kostela byly, podobně jako ve Fritzlaru, propojeny severní zdí trojlodí. Samostatné založení západní části kostela proto bylo jak v tomto, tak v dalších podobných případech technicky výhodným řešením. V holandském Leeuwardenu dokonce stavba ustrnula ve stadiu, které dobře ilustruje takový sled stavebních etap. Zamýšlená přestavba starobylého kostela sv. Víta byla v roce 1533 zastavena poté, co s odstupem od jeho západního průčelí byla dokončena mohutná západní věž zamýšlené pozdněgotické novostavby. Mezi novou věží a původním kostelem zůstal volný prostor (De Rijksdienst voor het Cultureel Erfgoed, Rijksmonumentenregister).

Za této situace může mezi východní částí kostelní stavby, která bývá dokončena jako první, a jeho západní částí (westwerkem, dvouvěžím apod.) zůstat volný a podle rychlosti postupu stavby různě dlouhou dobu nezastřešený prostor. $\mathrm{O}$ otevřeném prostoru mezi westwerkem a východní částí kostela v Lorsch se zmiňuje článek (Lammers 2005, 185-186), o nějž se opírá F. Laval. Vyhodnocení nálezové situace v Lorsch však bude třeba odložit do doby propojení a společného vyhodnocení výsledků archeologického a stavebněhistorického výzkumu.

V některých př́ipadech přestavba kostela přinesla nejen jeho zvětšení, ale i materiálovou proměnu. Románský westwerk kostela ve švédském Husaby lze díky dendrochronologickému datování jeho spodních partií (Braathen Dendrokronologiska Undersökningar) klást do prvního desetiletí 12. století (Sundner 1989). Představuje nejstarší část dochované stavby. Nevznikl však jako samostatně stojící věž určená $\mathrm{k}$ tomu, aby setrvala $\mathrm{v}$ pozici oddělené od svatyně. Byl první etapou přestavby staršího dřevěného kostela a jeho postupné proměny na větší kostel zděný. Nález pozůstatku sloupové konstrukce dřevěného předchůdce se podařilo dendrochronologicky datovat do 70. let 11. století. Způsob napojení západní zděné věže ke staršímu dřevěnému kostelu však nelze kvůli skrovnému rozsahu nálezu blíže rekonstruovat. Předpokládá se ale, že obě stavby spolu jistou dobu koexistovaly.

Výstavbu zděné věže v blízkosti staršího, dřevěného biskupského kostela ve Verdenu zmiňuje kronika merseburského biskupa Dětmara sepsaná zhruba mezi lety 1012-1018: Bernhard, který zastával biskupský úřad v letech 994-1014, „(...) započal stavbu kamenné věže u chrámu ve Verdenu, ačkoliv se v tom kraji kámen téměr nevyskytuje“ (Thietmarus Marsipolitanus, 234). Kronika byla uzavřena ještě před zahájením přestavby kostela na zděnou baziliku vysvěcenou $\mathrm{v}$ roce 1028 .

\section{Gottlandská paralela}

U samostatně stojících věží (kastalů), z nichž některé se vyskytují v blízkosti kostelů v jižním Švédsku a na Gottlandu, F. Laval rovněž hledal analogii významového vztahu, který předpokládá u středoevropských románských kostelů mezi jejich lodí a západní věží. Sledoval představu 
procesu postupného přibližování profánní věže ke svatyni, které vyústí v jejich spojení. Otázka funkce kastalů je dosud předmětem neuzavřené diskuse (Dahlberg-Sjöström 2015, 130-131). Dendrochronologicky se (Braathen Dendrokronologiska Undersökningar) zatím podařilo datovat jen stavbu kastalu v Gammelgarn do roku 1220. Možnosti bližšího posouzení tak mimo jiné uniká vztah stavební podoby kostela a staveb v jeho okolí v době vzniku kastalu. Představa, že vznik zděných kastalů předcházel přestavbě dřevěných svatyň na zděné (Berg 2004, 76), zůstává nadále v rovině hypotézy. Gottlandská společnost i přes absenci šlechty nebyla prosta sociálních rozdílů. Současný výzkum hledá roli kastalů nejen ve vztahu ke kostelu samému, ale především v rámci dvorů (gård) význačných majitelů. K centralizující funkci těchto dvorů náležel i kostel, který byl součástí jejich areálu, podobně jako v některých př́ípadech i kastal (Andrén 2009, 53). U gottlandských kastalů se klade důraz na jejich skladovací funkci, kterou se nabízí spojit s aktivitami vyšší vrstvy gottlandské společnosti v dálkovém obchodu. Neznamená to však, že by se odhlíželo od možnosti jejich využití jako útočiště v prŕípadě ohrožení. V románské zděné sakrální architektuře jižního Švédska a Gottlandu, která se pokládá za projev kulturního importu, se po překonání etapy prvních dřevěných kostelů uplatnily jak typy kostelních dispozic bez věží, tak i dispozice se západními věžemi vybavenými tribunami. Jakobsen (1993) uvádí, že přinejmenším polovina kostelů ve Skåne byla opatřena západní věží, a dovozuje, že většina z nich měla věžní tribunu. Kostel s věží tedy představoval i v této oblasti jasně vymezenou stavební úlohu, která i při zjevném podtextu osobní reprezentace neztrácela svůj dominantní duchovní rozměr (Wienberg 2010, 518-519). Př́itomnost kostela nebo kastalu viditelně ohlašovala společenský status majitele dvorce, aniž by tyto dva stavební a funkční celky musely spolu vzájemně souviset jinak než tím, že oba druhy staveb náležely k vybavení sídla význačného majitele (Johansson 2011). Nabízí se sice představa, že ve funkci reprezentační vertikály věže kostelů a kastaly alternovaly. Při nejistém stáří většiny kastalů a stavu analýzy stavebních proměn kostelů v jejich blízkosti je otázka posloupnosti vzniku obou druhů věží zatím obtížně řešitelná.

\section{Hlavní, přechodné a výjimečné užívání}

Počínaje úvahami nad způsoby, kterými byl uživán západní chór v Centule, vyvstala vedle slavnostní osobní reprezentace patrona a zakladatele i otázka dalších - zejména liturgických - funkcí západní části kostela. Podoba nedochovaného opatského kostela sv. Riquiera se rekonstruuje podle vyobrazení z počátku 17. století jako bazilika s východním i západním transeptem. Obě krŕžení hlavní lodi s transepty jsou zvýrazněna mohutnými věžemi. Západní transept - westwerk (ecclesia vel turris) obsahoval ve dvou patrech nad sebou tribuny obklopující liturgický prostor zasvěcený Kristu Spasiteli, který završovalo těleso západní věže. K jeho západní straně se na jižní a severní straně přimykaly schodištové věže. Westwerk skýtal prostory jak pro slavnostní přítomnost císařovu, tak pro zvláštní vánoční a velikonoční liturgii. V přízemí sloužil jako kostel farní. Útvar byl označován jako tres turres. Dobový popis průběhu bohoslužby zachycuje Institutio Sancti Angilberti de Diversitate Officiorum - dílo Angilberta, stavebníka baziliky v Centule a jejího opata v letech 790-814 (Möbius 1968, 119-125). Výtah uvádí Tomaszewski (1974, 363-364). Myšlenku sepětí západních prostor kostela s velikonoční liturgií, Božím hrobem, kultem sv. Michaela archanděla - průvodce duší a přeneseně s konáním mší za zemřelé členy řádu a patrony kostela a místem pohřbů význačných osobností sleduje v současné době řada badatelů.

Představu výlučného určení těchto prostor pro imperiální reprezentaci, tak jak ji zdůraznila starší německá literatura, současné bádání poněkud relativizuje (Pomfyová a kol. 2015). Ukazuje se navíc, že pluralita symbolických vrstev a jejich prolínání ke středověké sakrální stavbě patří, stejně jako prolínání skutečných provozních funkcí i neostrost hranic mezi různými způsoby užívání staveb či prostor uvnitř nich. Důvody, které vedly ke genezi stavebního typu, se nemusí nutně krýt se způsobem, jakým stavbu chápali její současníci a jak se užívala v době pozdější. Původní formotvorné důvody mohly časem ustoupit, být snad i zapomenuty a pak i dokonce chápány zcela odlišně. S tímto posunutým významem se opět mohly stát předmětem napodobování 
a přetváření. Výzkum severoevropských kostelů s věžemi kruhového půdorysu sleduje jejich odvození od rotundy Božího hrobu, s níž se místní elity seznámily za křížových výprav. Př́izemí těchto věží často sloužilo jako pohřební místo zakladatelů. Připomínka Božího hrobu a vzkříšení propůjčovala pohřebnímu místu zakladatelů a patronů zvláštní symbolický význam.

Skutečnost, že se některé z románských kostelních věží podobají bergfritům jak zjevem, tak způsobem využití některých prostor, sama o sobě neznamená, že tribunový kostel se západní věží vznikl spojením svatyně a profánní věže. Nabízí se však dále sledovat, jak se starší představa kostela $\mathrm{s}$ věží v nových podmínkách přizpůsobovala aktuálním potřebám. Současný pohled na fungování středověkých staveb relativizuje představu jednoúčelového využívání prostor. Podrobnější výzkumy užívání staveb i jejich částí ukazují jako přriměřenější chápat je v rozdílných rovinách hlavního/typického způsobu užívání přechodného nebo zcela výjimečného (Huitson 2014). Variantní pojímání možností, které stavba skýtá, dokládá názor opata Sugera ze St. Denis, když zmiňuje, že věž a horní cimbuří kostela může sloužit jak k ozdobě, tak k užitku kostela: „Turrim etiam et superiora frontis propugnacula tam ad ecclesie decorem quam et utilitatem, si oportunitas exiget, variari condiximus" (Speer-Binding 2000, 322; obr. 13). I když není snadné ani po předchozích úvahách hlavní funkci věže výstižně vymezit, je zjevné, že skladování, uschovávání věcí a případné útočiště osob patří spíše k rovinám doplňkovým a přechodným (obr. 14A-D).

Ani funkce zvonice, kterou uváděl V. Mencl jako první, zřejmě nemusela být sama o sobě natolik určující, i když byla nepochybně významná. Věže natolik udivujících rozměrů, jako například věž kostela ve Svojšíně, datovaná podle lešení káceného v zimě 1159/1160, se značnou kubaturou zabudovaného zdiva, ale i věže skromnější jsou asi jen stěží vysvětlitelné pouze jako stavby sloužící k nesení zvonů (Hauserová a kol. 2011). Pro zvonění samo se jistě nabízela řešení méně rozmařilá. S výstavbou horní části věže jako samostatnou stavební etapou po blíže neuchopitelné prodlevě se u románských věží často setkáváme. Spodní část obsahující tribunu se dokončovala v předstihu. Výstavba horní části věže (části stavby pro provoz kostela v podstatě zbytné) byla zároveň vnímána jako př́ležitost k reprezentaci patrona kostela: viz Lenešice nebo

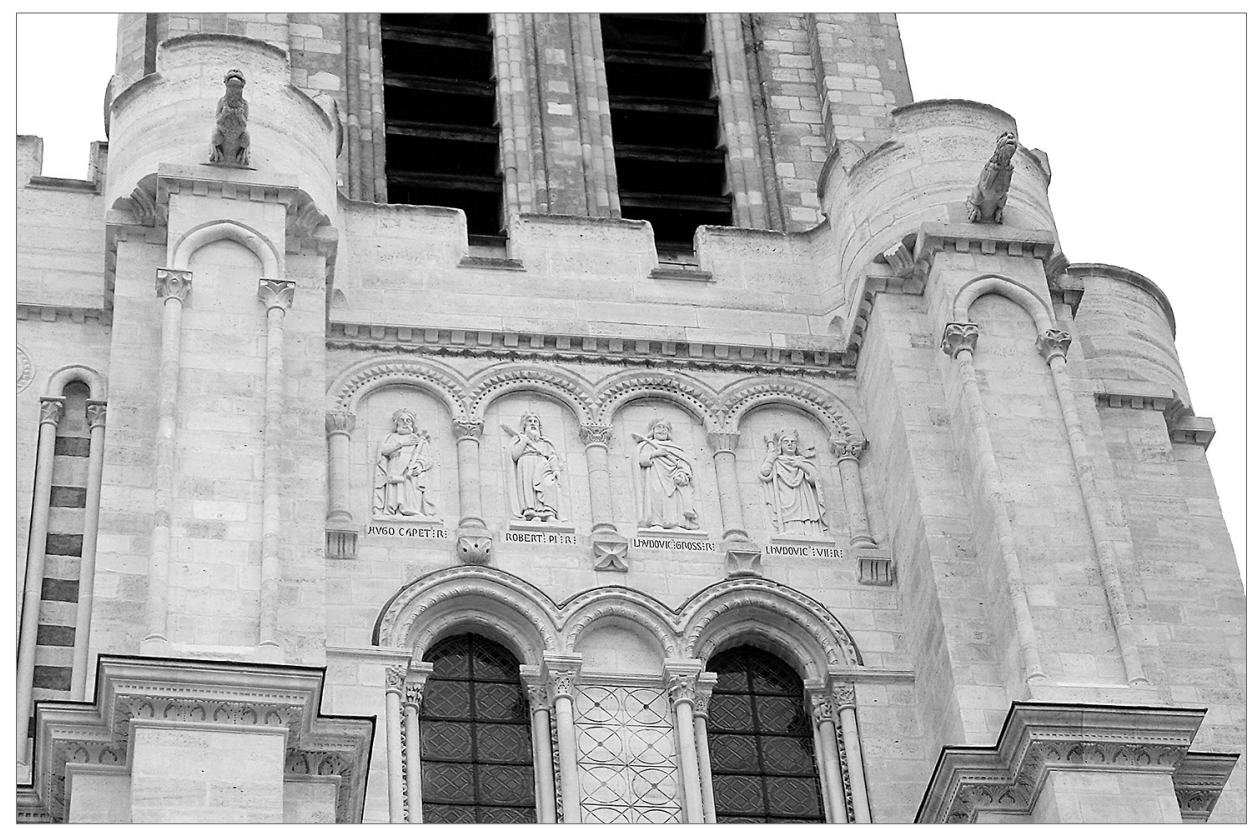

Obr. 13. Cimbuří na jižní věži v západního průčelí klášterního kostela St. Denis (Pařiž, Francie). Foto M. Hauserová. Abb. 13. Zinnen am Südturm in der Westfassade der Klosterkirche St. Denis (Paris, Frankreich). Foto M. Hauserová. 


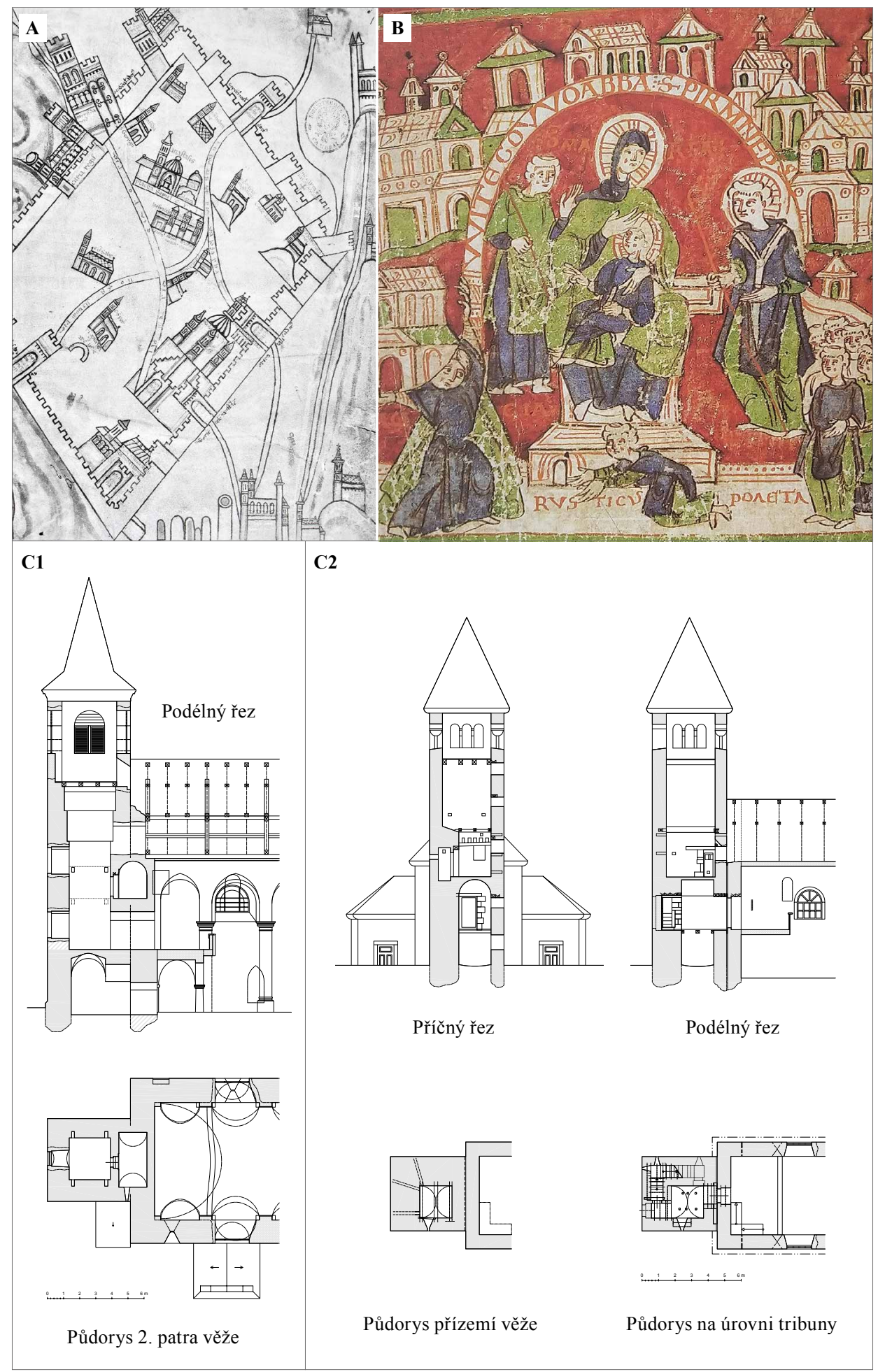


D
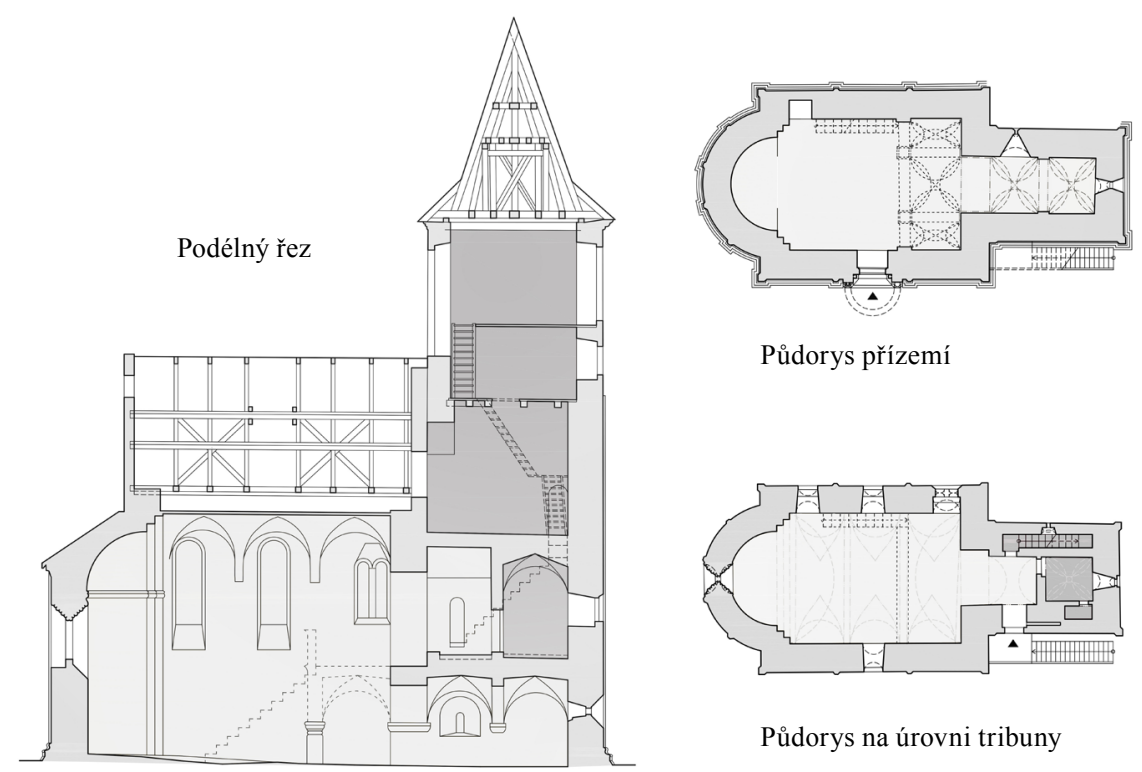

Půdorys př́zemí

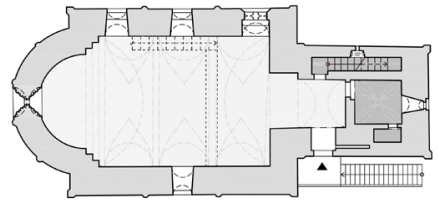

Půdorys na úrovni tribuny

Obr. 14. Symbolická i užitková role věže. A - Vžitá silueta kostela s věží v roli obecně srozumitelného zástupného znaku pro kostel. Plán Jeruzaléma z Kolektáře z Cambrai, vznik mezi 1140 a 1170 (podle Legner 1985, III., 73). B - Nakupení věží naznačuje vznešenou výpravnost dějiště: Panna Maria patronka kláštera v Reichenau mezi jeho budovatelem opatem Witigowo a zakladatelem kláštera Pirminem. Carmen de Gestis Witigowonis Abbatis, konec 10. století (podle Legner 1985, I., 247). C - Skladovací prostory/trezory ve věžích v kostela. C1 - Kostel Nanebevzetí P. Marie v Čelákovicích (podélný řez věží a přilehlou částí lodi). Trezor je umístěn v masivu k sobě přiložených zdí lodi a věže, jeho vstup je dosažitelný pouze se žebř́íkem. Trezor je prakticky nespalný a je uzavíratelný zevnitř (zaměření, analýza a grafické zpracování M. Falta). C2 - V kostele sv. Maří Magdalény v Pařižově (podélný řez) je skladovací prostor umístěn v přízemí věže. Je přístupný pouze seshora poklopem v podlaze samostatně uzavíratelného prostoru v prvním věžním patře, které bylo přístupné jak portálem zvenčí, tak z tribuny v lodi kostela (zaměření, analýza a grafické zpracování M. Falta). D - Obraz věže jako samostatného útvaru se nemusí krýt s vnitřní prostorovou a funkění organizací stavby. V kostele ve Vroutku (podélný řez kostelem s pohledem na jižní stěnu; prostory oddělené od lodi vybarveny tmavě šedě) proniká prostor kostelní lodi i do tělesa věže. $\mathrm{V}$ př́izemí se celé podvěží stalo součástí liturgického prostoru lodi, v patře s lodí splývá i část tribuny zasunutá do tělesa věže. Neliturgický prostor v západní části prvního patra věže je opatřen trezorem v tloušt’ee zdi. $Z$ druhého patra věže se rovněž pủvodně otevíral prủhled do lodi (zaměření M. Radové doplnila M. Hauserová, grafické zpracování H. Vaňková a M. Falta).

Abb. 14. Symbolische und Nutzungsrolle eines Turms. A - Gängige Silhouette einer Kirche mit Turm in der Rolle eines allgemeinverständlichen repräsentativen Merkmals für eine Kirche. Plan von Jerusalem aus einem Kollektarium von Cambrai, Entstehung zwischen 1140 und 1170 (nach Legner 1985, III., 73). B - Die Häufung von Türmen deutet auf die erhabene Ausstattung des Schauplatzes hin: Jungfrau Maria die Patronin des Klosters in Reichenau zwischen seinem Erbauer Witigowo und dem Klostergründer Pirminius. Carmen de Gestis Witigowonis Abbatis, Ende 10. Jhdt. (nach Legner 1985, I., 247). C - Lagerräume/Tresore in Kirchtürmen. C1 - In der Mariä Himmelfahrtskirche in Čelákovice (Längsschnitt der Türme und angrenzender Teil des des Schiffs) wurde im Gemäuer der aneinander liegenden Wände von Schiff und Turm ein Tresor untergebracht, dessen Eingang nur mit einer Leiter erreichbar ist. Der Tresor ist praktisch feuerfest und von Innen verschließbar (Vermessung, Analyse und grafische Aufbereitung M. Falta). C2 - In der Maria Magdalenenkirche in Pařížov (Längsschnitt) ist im Erdgeschoss des Turms ein Lagerraum untergebracht. Er ist nur von oben durch eine Falltür im Fußboden des selbständig abschließbaren Raumes im ersten Turmgeschoss zugänglich, das sowohl vom Außenportal als auch von der Empore im Kirchenschiff aus zugänglich war (Vermessung, Analyse und grafische Aufbereitung M. Falta). D - Das Bild eines Turms als eigenständiges Gebilde muss sich nicht mit der inneren räumlichen und funktionalen Organisation des Baus decken. In der Kirche in Vroutek (Längsschnitt der Kirche mit Blick auf die Südwand; vom Schiff abgetrennte Räume dunkel grau gefärbt) reicht der Raum des Kirchenschiffs auch bis in den Turmkörper hinein. Im Erdgeschoss wurde der Raum unter dem Turm Teil des liturgischen Bereichs des Schiffs, im ersten Stock geht auch ein Teil der in den Turmkörper hineinreichenden Empore in das Kirchenschiff über. Der nichtliturgische Bereich im Westteil des ersten Turmgeschosses ist mit einem Tresor in Mauerstärke versehen. Vom zweiten Turmgeschoss eröffnete sich ursprünglich ebenfalls eine Durchsicht ins Schiff (die Vermessung von M. Radová wurde von M. Hauserová ergänzt, grafische Aufbereitung H. Vaňková und M. Falta). 
Sluhy. Ve Svojšíně je u paty této části zazděn reliéf, který byl zvláště dobře viditelný pro ty, kdož vstupovali na tribunu zvnějšku portálem na úrovni prvního patra.

Zároveň existence věže nebyla nutnou podmínkou pro používání zvonů. Písemné prameny svědčí o různých zvonicích zcela nebo částečně dřevěných, které stály bud' samostatně (campanaria), nebo byly jinak stavebně svázány se svatyní (k tomu Binding-Lindscheid-Burdich 2002, 403-439).

Zvony, resp. zvuk vyzvánění, byly, jak dobové prameny nasvědčují, chápány jako jeden z prostředků, které přispívají k výzdobě kostela. Zvuky zvonů a zvony samy byly zahrnuty mezi „ornamenta ecclestiaca“. Zvony představovaly cenný majetek. Uplatňovaly se jako drahocenný, a zároveň tedy reprezentační dar. Jejich akustická i spirituální funkce je známa. Od karolínského období se zmiňuje jejich svěcení. Účel svolávání křest’anské obce, které cítíme v pozadí jednoho z termínů pro ně užívaných - signum (lat. znamení), může indikovat veřejný charakter svatyně opatřené zvonicí. Jako signa ecclesiae byly označeny zvony chované v západním dvouvěží kostela v Lorsch, které F. Laval s odkazem na mladší označení stavby jako castellum $(2016,53)$ uvádí do souvislosti s profánními věžemi téhož označení. Ze závěrů koncilu v Cáchách z roku 801 je zřejmé, že zvonění je vnímáno jako posvátný úkon. Zvoník má proto být osobou duchovní. Koncil z roku 817 stanovil počty zvonů podle druhu kostelů. Farní kostely měly mít zvony alespoň dva. V polovině 10. století Ordo Romanus uvádí, že zvuk zvonů svolává k bohoslužbě (Friske 2007, 191; obr. 15). Na Vyšehradě v roce 1004 však svolávaly Jaromírovy podporovatele do boje proti Polákům (Thietmarus-Neškudla-Žytek 2008, 166). Vůbec nejstarší evropský dochovaný bronzový zvon z kostelní věže v Caninu u Viterba má na okrajích nápis, který jej zasvěcuje Kristu a archandělu Michaelovi (Beck-Steuer-Timpe 1998, 212). Zůstává jistě otázkou, jak se požadavek na vybavování kostelů zvony dařilo ve skutečnosti naplňovat.

Zděná svatyně kromě vznešenosti svého zjevu zároveň skýtala jinak jen velmi obtížně dosažitelné kvality: nespalnost, trvanlivost a odolnost, které byly v podmínkách tradiční stavební kultury středovýchodní a severní Evropy hůře slučitelné s přijatelnými parametry obytnosti případného souvisejícího sídla. Je přirozené, že potenciál zděných kostelů nijak významně neoslovoval tam, kde se k uspokojení potřeb a ambicí stavebníků nabízely jiné atraktivnější prostředky. Příznačně to můžeme pozorovat $\mathrm{v}$ románském Alsasku s ranými rodovými hrady vybavenými kaplemi a reprezentačními klášterními fundacemi panovníka a šlechty. Kostelům ve zdejším venkovském prostředí zbývalo právě jen jejich primární poslání. Nepřekvapuje tu proto převaha kostelů s věžemi nad chórem. Vertikála chórové věže navenek zdůrazňovala nejvýznamnější část kostela - oltářní prostor. Další praktická využitelnost takové věže byla kvůli obtížné př́stupnosti jejích horních pater značně omezena. Některé z nich nebyly př́istupné vůbec (obr. 16A-C).

Podoba účelových kombinací liturgických a dalších funkcí ve stavebním tělese kostela byla $\mathrm{v}$ důsledku místních podmínek a stavebních zvyklostí velmi rozmanitá. V některých případech úpravy pro doprovodné funkce následovaly s odstupem. V dánských zděných patrových centrálách se spojila funkce svatyně s rolí pevného útočiště. V některých př́ípadech snad dovolovaly i aktivní obranu. Mohutné západní věže kostelů v severním Německu, Dánsku a Švédsku měly rovněž potenciál jak útočištný, tak skladovací. Úložnou a ochrannou funkci i v lodi kostela, kde byly ukládány podle stanoveného pořadí vzácnosti, mezi nimi obilí, připomíná G. Entz. Nemuselo se přitom jednat pouze o majetek patrona kostela. Pokud budeme brát v úvahu ustalování farních funkcí, pak nelze vyloučit ani uložení vybraného desátku. O takovém využití prostoru ve třetím patře věže v Idensen uvažuje Günther $(2010,125)$. Tutéž funkci přičítají někteří autoři také gottlandským kastalům. Mohutné útvary západních kostelních věží (tzv. westwerky) však nelze spojovat se steinwerky, které jsou na rozdíl od nich vybaveny pro obývání. Důležitým znakem steinwerku (kemenate) je možnost vytápění. V kaplových věžích úsporných hradních jader v jižním Německu byly nad sebou v jednom zděném věžovitém tělese situovány prostory různých funkcí. Nejspodnější úroveň vyplňoval skladovací prostor, střed zaujímala plně vyvinutá kaple s tribunou. Nad ním bylo situováno útočištné patro. Opět se jednalo o stavební útvar s kumulovanou funkcí, který úsporně naplnil praktické i symbolické funkce pevné věže s využitím tělesa kaple (Fuchs 2003). V některých případech těchto svatyň je prameny doložena funkce soukromé nebo poloveřejné hradní kaple (Záruba 2017, 104). 


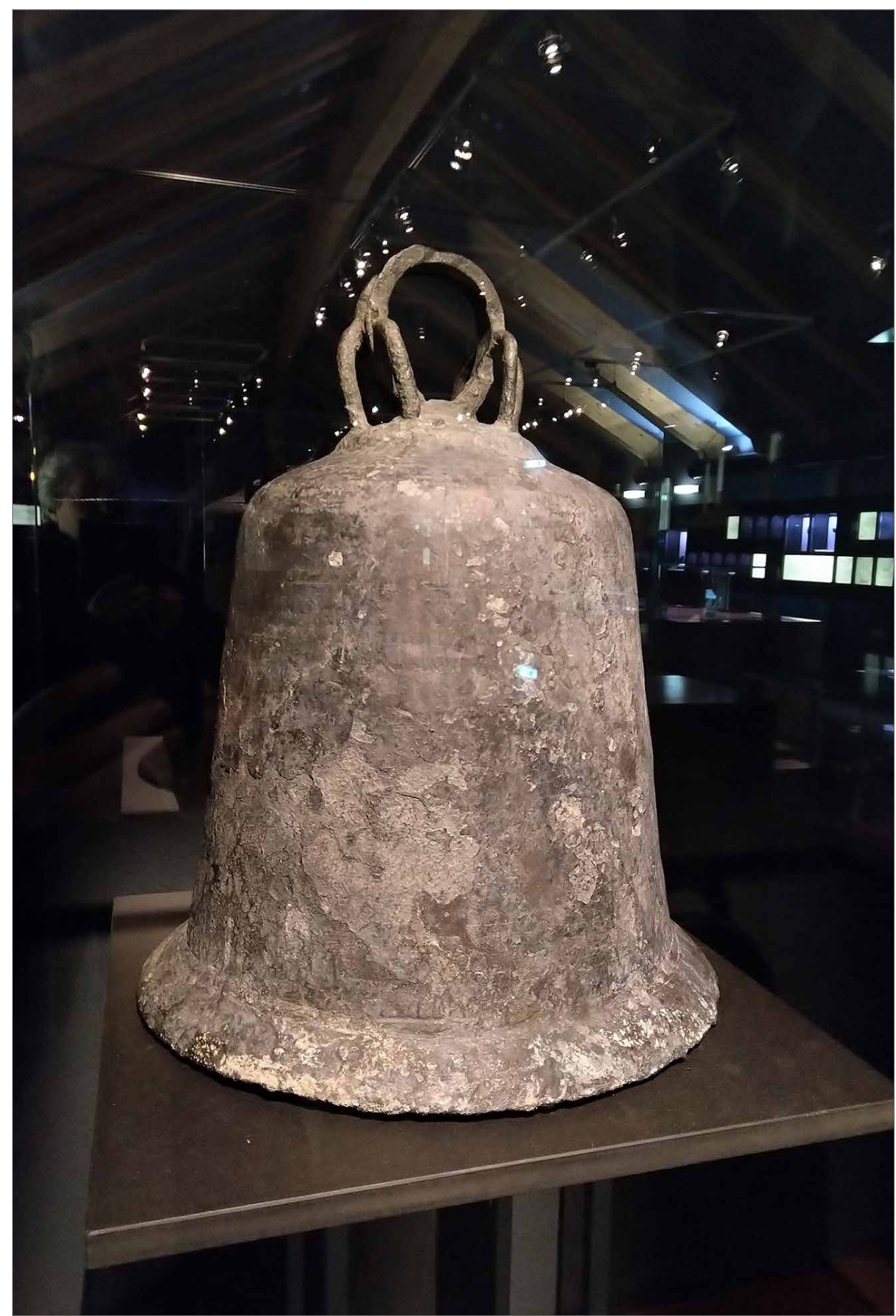

Obr. 15. Zvon objevený při archeologickém výzkumu př́stavu Haithabu/Schleswik, 10. století. Vyzvánění je zde písemně doloženo již roku 854. Foto M. Hauserová.

Abb. 15. Bei einer archäologischen Grabung in Haithabu/Schleswig entdeckte Glocke, 10. Jhdt. Bereits im Jahr 854 ist dort ein Läuten schriftlich belegt. Foto M. Hauserová. 

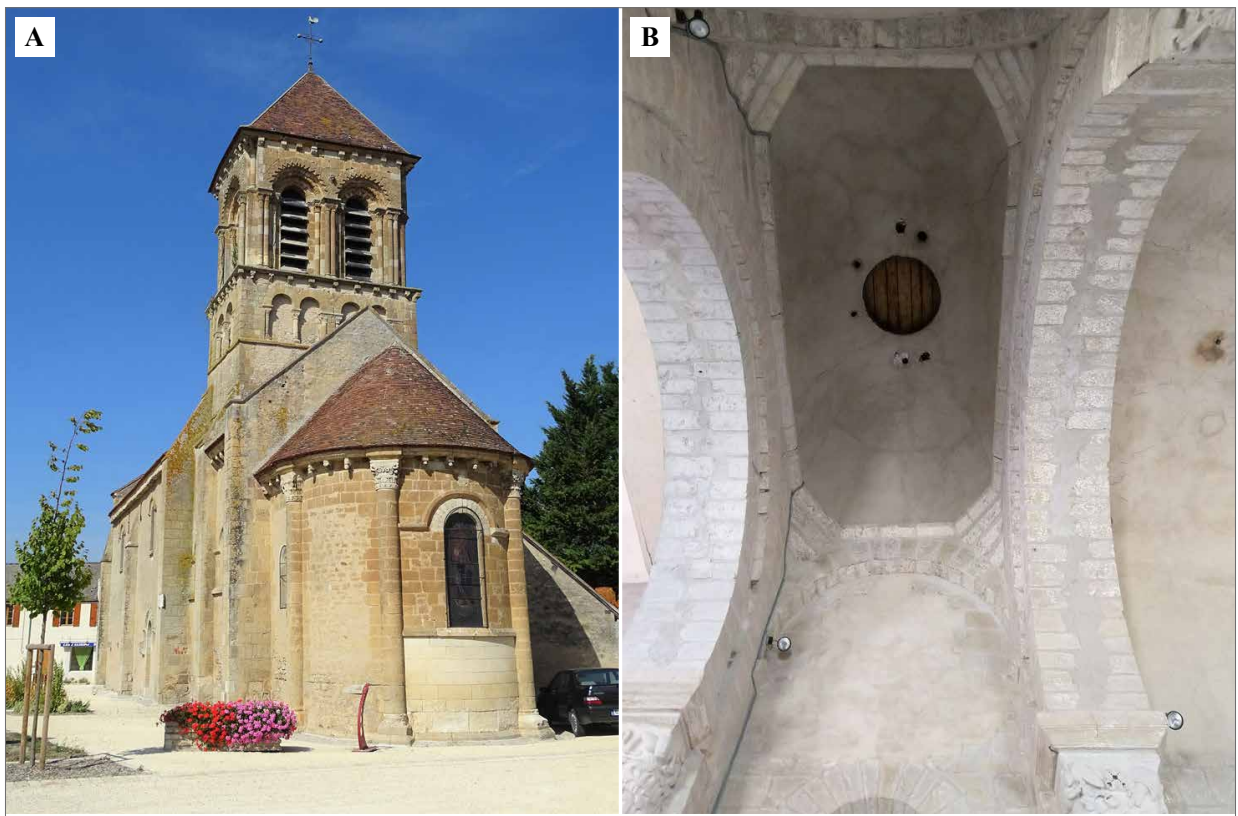

C

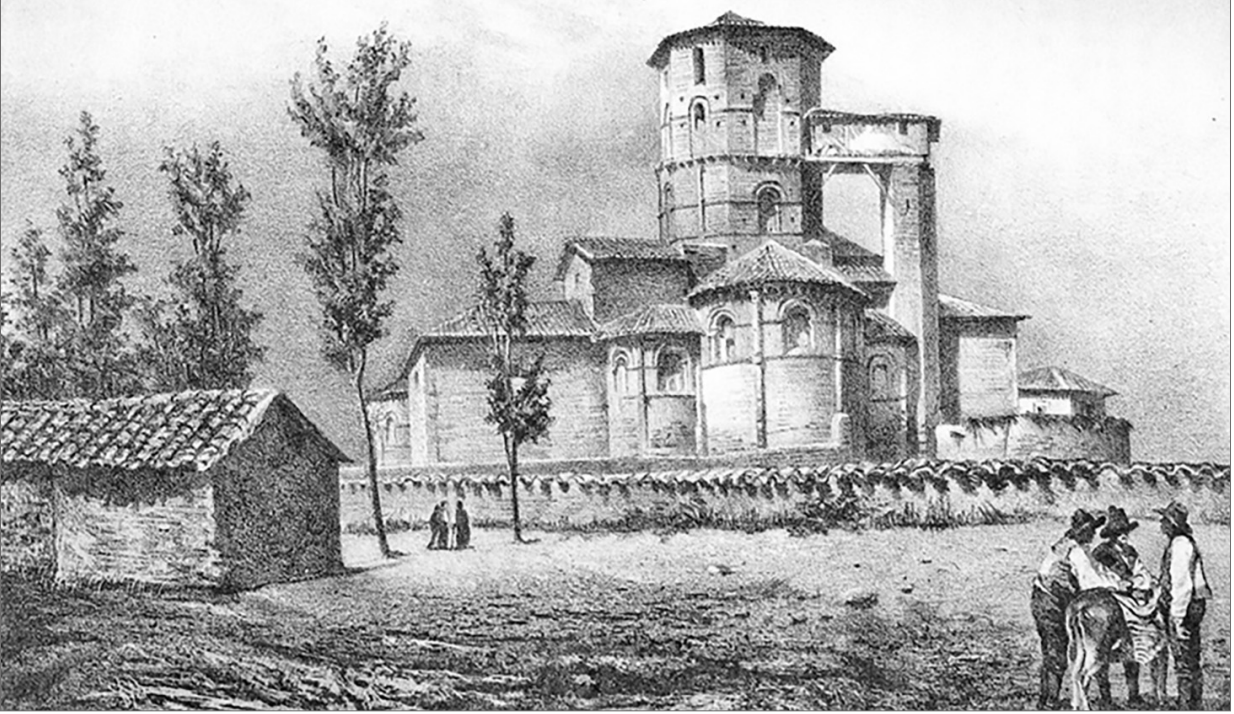

Obr. 16. Příklady obtížně př́ístupných věží, které se uplatňují především jako vizuální symbol a zároveň jako zvonice. A venkovský kostel Saint Roch s typickou chórovou věží, Neuilly-en-Dun (Cher, Francie); B - zvonici nad jeho chórem s prostorem chóru spojuje pouze průlezný otvor ve klenbě umožňující zároveň vedení lan ke zvonům (foto M. Hauserová); C - věž nad křižením kostela San Martín de Tours ve Frómistě (Castilla y Léon, Španělsko), kresba Francisca J. Parcerisa „Recuerdos y bellezas de España. Palencia“ (1861) zachycuje dodatečně zř́zený a při restauraci v roce 1904 opět odstraněný př́istup do zvonové komory.

Abb. 16. Beispiele für schwer zugängliche Türme, die vor allem als visuelles Symbol und gleichzeitig als Glockenturm dienen. A - Dorfkirche Saint Roch mit typischem Chorturm, Neuilly-en-Dun (Cher, Frankreich); B - der Glockenturm über dem Chor ist mit dem Chorraum nur durch eine Einstiegsöffnung im Gewölbe verbunden, die gleichzeitig die Führung der Seile zu den Glocken ermöglicht (Foto M. Hauserová); C - Turm über der Vierung der Kirche San Martín de Tours in Frómista (Castilla y Léon, Spanien), Die Zeichnung von Francisco J. Parcerisa „Recuerdos y bellezas de España. Palencia“ (1861) stellt den nachträglich angelegten und bei der Restaurierung von 1904 wieder entfernten Zugang zur Glockenkammer dar. 


\section{Závěr}

Zděné románské tribunové kostely, které si spojujeme s představou sídel rané nobility, sloužily jako svatyně $\mathrm{v}$ duchovní správě i jako nástroj reprezentace. Jejich stavební podoba $\mathrm{v}$ řadě př́ípadů nasvědčuje tomu, že umožňovaly relativně bezpečné uložení věcí a přechodný úkryt osob. $\mathrm{K}$ zajištění těchto funkcí byly dokonce zřizovány zvláštní místnosti. Ve vzácných př́ípadech zůstaly dodnes v patrech věží zachovány i prostory, které připomínají drobná oratoria. Prostory tohoto zvláštního určení se nacházely v různých vazbách na reprezentační tribunovou část vlastníka - patrona kostela. Západní věž pro ně pochopitelně skýtala př́íhodný prostor. Je však třeba mít na mysli i tu skutečnost, že nesnadno vyčíslitelný, avšak nikoliv nevýznamný díl zděných románských tribunových kostelů zděnou věž zřejmě neměl. Uvádět konkrétní podoby stavebních řešení, $\mathrm{v}$ nichž se mohly $\mathrm{v}$ kombinaci se zdivem různými způsoby uplatňovat i zaniklé dřevěné části, a odlišit je od staveb od počátku zcela bezvěžových přesahuje účel tohoto textu. I kostely bez zděné západní věže však mohly být v tehdejším prostředí pro svou výlučnost vnímány jako stavby výstavné a reprezentativní.

Doprovodné funkce kostela byly často vázány právě na jeho západní část s věží. Tato skutečnost samozrrejmě nevylučovala, že jeho vnější podoba mohla asociovat významy, které se pojily se známými motivy z monumentální sakrální i profánní architektury a které nesly sdělné symbolické obsahy. Významuplná vertikála věže byla (nejen) ve středověké architektuře jevem zcela obecným, jehož užívání se nevázalo na ten či onen typologický druh staveb. Obecné roviny významového obsahu věže byly přirozeně společné stavbám církevním i světským. Zděné románské kostely se v době, kdy se začaly stavět ve středovýchodní a severní Evropě, staly zjevem mimořádným. Nejen přítomnost věže, ale už náročnost zděné stavby samé mohla srozumitelně svědčit o možnostech a ambicích svého stavebníka. Příspěvek ukazuje výskyt malých románských tribunových kostelů se západní věží i v západní a severní Evropě. Jejich rozšíření, které spojuje prostředí západoevropské kultury s děním na okrajích působení latinské církve, nabízí jistou korekci úvah o původu a významu tohoto stavebního druhu, který se spojuje s dvorci nobility a který zjevně naplňoval i reprezentační ambice svých stavebníků. Příklady etapizované výstavby kostelů upozorňují na úskalí výkladu situací svatyň se samostatně stojící věží.

Př́íspěvek dále naznačuje, že do představ o chápání kostela by však měl být komplexněji zahrnut způsob, jakým jejich podobu a společenskou roli vnímali aktéři jejich výstavby a užívání. Jak se v konkrétních kulturních podmínkách rozumělo poselství vyjádřenému stavební formou spojující lod' a věž? Hypotézy, které z interpretačního pole významů kostelní věže vybírají právě oblast profánní, situaci zjednodušují. Cílem tohoto textu bylo mimo jiné ukázat, že vedle nově navrženého pohledu na význam kostelní věže a kostela samého existuje nepřehlédnutelná a prameny doložená vrstva dalších symbolických významů, které byly v době vzniku kostelů ve střední a středovýchodní Evropě již zažity a pevně spojeny s představou sakrální stavby. Přiblížit se tomu, čím stavební dílo jako symbolický systém oslovovalo tehdejšího člověka a jak bylo díky tomu možné jeho utvářením komunikovat, je ovšem svébytným úkolem velmi komplexní povahy, který si bezpochyby vyžádá další mezioborovou diskusi.

\section{Prameny}

FRB II: Fontes Rerum Bohemicarum II (Emler, J., ed.). Praha 1874.

Urkundenbuch des Hochstifts Naumburg. Teil 1 (967-1207) (Rosenfeld, F., ed.). Magdeburg 1925.

Statuta Capitulorum Generalium ordinis Cisterciensis ab anno 1116 ad annum 1786. Tomus I (Canivez, J. M., ed.). Louvain 1933. 


\section{Literatura}

ANDRÉN, A., 2009: Vem lät bygga kyrkorna på Gotland?, Saga och Sed. Kungl. Gustav Adolfs Akademiens Årsbok 2009, 31-59.

BALDOVIN, J. F., 1987: The Urban Character of Christian Worship. The Origins, Development, and Meaning of Stational Liturgy. Roma.

BANDMANN, G., 1951: Mittelalterliche Architektur als Bedeutungsträger. Berlin.

BECK, H.-STEUER, H.-TIMPE, D., edd., 1998: Reallexikon der germanischen Altertumskunde. Bd. 2. Berlin - New York.

BENEŠOVSKÁ, K., 2010: Magistri cum machinis, maestri commachini nebo maestri campionesi. In: Čechy jsou plné kostelů = Boemia plena est ecclesiis. Kniha k poctě PhDr. Anežky Merhautové, DrSc. (Studničková, M., ed.), 235-237. Praha.

BERG, E., 2004: Vyer från kastaler, kastell och kaserner. Stockholm.

BINDING, G.--LINSCHEID-BURDICH, S., 2002: Planen und Bauen im frühen und hohen Mittelalter nach den Schriftquellen bis 1250. Darmstadt.

BINDING, G.-SPEER, A., edd., 2000: Abt Suger von Saint-Denis. Ausgewählte Schriften: Ordinatio, De consecratione, De abministratione. Darmstadt.

CLAUSSEN, H., 2002: Karolingische sinopien und Stuckfragmente im Corveyer Westwerk. In: Sinopien und Stuck im Westwerk der Karolingischen Klosterkirche von Corvey (Poeschke, J., ed.), 9-48. Münster.

ČECH, P., 2004: Žatec v raném středověku. In: Žatec (Ebelová, I.-Holodňák, P., edd.), 54-114. Praha.

ČECHURA, M., 2002: Opevněný kostel v Řesanicích, CB 8, 375-380.

DAHLBERG, M.-SJÖSTRÖM, I., edd., 2015: Skåne: landskapets kyrkor, Riksantikvarieämbete, 130-131. Stockholm. Dostupné z: http://kulturarvsdata.se/raa/samla/html/9023.

DEHIO, G., 2005: Handbuch der Deutschen Kunstdenkmäler. Rheinland. Deutscher Kunstverlag.

ERBACH-SCHÖNBERG, M., zu a kol., 2011: Erbach-Schönberg, M., zu-Pinsker, B.-Untermann, M.Zeeb, A., Kloster Lorsch. Petersberg.

FRISKE, M., 2007: Mittelalterliche Kirchen im westlichen Fläming und Vorflaming Kirchen im ländlichen Raum. Bd. 5. Berlin.

FUCHS, F., 2003: Höfische Kapellen des Landadels in der Region Regensburg. In: Dvorské kaple vrcholného a pozdního středověku a jejich umělecká výzdoba (Fajt, J., ed.), 214-221. Praha.

GROSSMAN, D., 1957: Zum Stand der Westwerkforschung, Wallraf-Richartz-Jahrbuch 19, 253-264.

GÜNTHER, H. J., 2010: Sigwardskirche in Idensen - Eine romanische Kirche im Tal der Westaue. Wunstorf.

HANSEN, K., 2013: Vem satt på läktaren? Fyra typer av emporer i skånska kyrkors romanska västtorn, Fornvännen, 178-195.

HASIL, J.-NOVÁK, D., 2012: Kostel sv. Mikuláše v Potvorově. Postřehy k okolnostem bádání a jejich interpretačním důsledkům, Svorník 10, 173-188.

- 2020: Diskontinuity historické archeologie v Čechách? Několik poznámek ke studiu stř̌edověkých elit Diskontinuitäten der historischen Archäologie in Tschechien? Einige Anmerkungen zum Studium mittelalterlicher Eliten, AH 45, 831-833. https://doi.org/10.5817/AH2020-2-15

HAUSEROVÁ, M., v př́ípravě: Die Emporenkirche in Böhmen im Licht der baugeschichtlichen Forschung. Sborník z konference „Vlastnické kostely, dvorce, sídla a vývoj raných elit ve střední Evropě“, 26.-28. května 2010, Kutná Hora.

HAUSEROVÁ, M. a kol., 2011: Hauserová, M.-Nováček, K.-Čechura, M.-Falta, M., Románský kostel sv. Petra a Pavla ve Svojšíně, PRP XVIII, č. 1, 5-30.

HOLZINGER, G. W., 1962: Romanische Turmkapellen in Westtürmen überwiegend ländlichen Kirchen im südlichen Teil des alten Erzbistums Köln. Aachen.

HORÁČKOVÁ, M., 2014: Angilbertova stavební zpráva o Saint-Riquier. Diplomová práce na FF MU, Brno. HUITSON, T., 2014: Starway to Heaven, The Functios of Medieval Upper Spaces. Oxford - Philadelphia.

HUMBACH, R., 2005: Dom zu Fritzlar. Mit einem Dokumentationsanhang. Petersberg.

CHARRUADAS, P.-LAYEUX, M., 2014: La chapelle Sainte-Anne à Auderghem et le chanoine Lemaire. Mise au point sur une église « romane» et sa restauration (1915-1917). In: Trulla et cartæ. Culture 
matérielle, patrimoine et sources écrites. Liber discipulorum et amicorum in honorem Michel de Waha (F. Chantinne, F.-Charruadas, P.-Sosnowska, P., edd.), 387-432. Bruxelles.

JAKOBSEN, H., 1993: Romanske vesttårne, deres indretning og funktion, Vesttårne før 1300 i det middelalderlige Danmark øst for Storebælt. Lund Studies in Medieval Archaeology 12. Stockholm.

JOHANNSON, H., 2011: Kyrkor, kastaler och storgårdar på södra Gotland. En analys av kyrkans och kastalens relation till storgårdar I Öja, Hamra och Sundre. Diplomová práce, Stockholms universitet.

KARLSSON, M., 2015: Kyrkorna under äldre medeltid. In: Dahlberg, M.-Sjöström, I., Skåne, landskapets kyrkor, 39-110. Stockholm.

KLÁPŠTĚ, J., 1991: Pamět' krajiny středověkého Mostecka. Most.

- 1994: Změna, středověká transformace a její předpoklady, Mediaevalia archeologica Bohemica 1993, 9-59.

- 2005: Proměna českých zemí ve středověku. Praha.

KLOSTER LORSCH. Vom Reichskloster Karls des Großen zum Weltkulturerbe der Menschheit. Ausstellung Museumszentrum Lorsch, 28. 5. 2011 - 29. 1. 2012. Petersberg.

KRANZBÜHLER, E., 1905: Verschwundene Wormser Bauten. Beiträge zur Baugeschichte und topographie der Stadt. Worms.

KRÜGER, K., 2003: Architecture and Liturgical Practice: The Cluniac galilea. In: The White Mantle of Churches. Architecture, Liturgy, and Art around the Millennium (Hiscock, N., ed.), 139-159. Turnhout.

-2003a: Die romanischen Westbauten in Burgund und Cluny. Untersuchungen zur Funktion einer Bauform. Berlin.

LAMMERS, D., 2014: Aktuelle archäologische Ergebnisse zur Gründungsgeschichte des Klosters Lorsch. In: Gründung im archäelogischem Befund. Mitteilungen der Deutschen Gessellschaft für Archäologie des Mittelalters und der Neuzeit 27, 181-190. Paderborn.

LAVAL, F., 2016: Co je kostel? K počátkům šlechtických sídel českého středověku, AR LXVIII, 47-90.

LAWRENZ, C., 2003: Architektur und Herrschaftsanspruch, Die Baukunst Kaiser Lothars III. (1125-1137) und seiner Parteigänger. Ein Beitrag zur sächsischen Architektur des 12. Jahrhunderts. Berlin.

LEGNER, A., ed., 1985: Ornamenta ecclesiae. Kunst und und Künstler der romanik. I.-III. Köln.

LÍBAL, D., 1984: Urbanistický i architektonický fenomén středověkých západních Čech, Minulostí Západočeského kraje 20, 133-144.

MENCL, V., 1965: Panské tribuny v naší románské architektuře, Umění XIII, 29-62.

MÖBIUS, F., 1968: Westwerkstudien. Jena.

- 1968a: Zur Deutung des karolingischen Westwerks, Acta Historiae Artium XIV, 119-125.

PFEIFFER, M., 1990: Architektur als Zitat - die Chorapsis. In: Schäden an Wandmalereien und ihre Ursachen (Möller, H.-H., ed.), 68-74. Hannover.

PLATZ, M. M., 2017: Neues zur Baugeschichte der Elisabethkirche in Marburg an der Lahn. Dostupné z: https://minuseinsebene.hypotheses.org/1167.

POMFYOVÁ, B. a kol., 2015: Stredoveký kostol. Historické a funkčné premeny architektúry. 1. díl. Trnava.

PRIX, D., 2009: Vrcholně románské Čechy. In: Benešovská, K.-Kratochvíl, P., Velké dějiny zemí Koruny české, 30-42. Praha.

PRIX, D.-VŠETEČKOVÁ, Z., 1993: Středověký kostel sv. Bartoloměje v Praze 9 - Kyjích do počátku husitských válek, Umění XLI, 231-258.

RADOVÁ, M., 1996: Idensen. K úvahám nad západní tribunou románského kostela - Idensen. Erwägung über die Westtribüne der romanische Kirche, AH 21, 281-287.

RIMPEL, B., 2011: Mittelalterliche Turmvorhallen norddeutscter Backsteinkirchen. In: Werk und Rezeption - Architektur und ihre Ausstattung: Festschrift Ernst Badstübnerzum 80. Geburtstag (Kunz, T.Schuman, D., edd.), 189-217. Berlin.

SCHÖNFELD DE REYES, D., 1999: Westwerkprobleme - zur Bedeutung der Westwerke in der kunsthistorischen Forschung. Weimar.

SUGER 2003: Skutky opata Sugera, Bernard z Clairvaux opatu Sugerovi, Nač je v chrámu zlato?; Vilémův životopis opata Sugera; Erwin Panofsky: Suger, opat ze Saint-Denis. Vybral a uspořádal Petr Šourek, přeložili Petr Šourek (latinské texty) a Lubomír Konečný. Praha.

SUNDNER, B., ed., 1989: Dendrokronologi och medeltida kyrkor. Symposium in Lund 11-13 april 1988. Lund Studies in Medieval Archaeology 6. Lund. 
TAJKOV, P., 2010: Emporové kostoly na Zemplíne. Poznámky k románskym dedinským kostolom s vežou nad emporou, Ochrana pamiatok 22, 333-356.

THIETMARUS MARSIPOLITANUS 2008: Kronika. Dětmar z Merseburku. Z lat. originálu přeložili B. Neškudla [verše] a J. Žitek Praha.

TOMASZEWSKI, A., 1974: Romańskie kościoły z emporami zachodnimi na obszarze Polski, Czech i Węgier. Wrocław.

VERGNOLLE, E., 1985: St-Benoît-sur-Loire et la sculpture du XIe siècle. Paris.

VARHANÍK, J., 1989: Věžní empora kostela sv. Jiljí v Miroticích a její typ, Památky a příroda 14, 82-87.

WIENBERG, J., 2010: Romanesque Round Church Towers in Scandinavia. In: Zwischen Fjorden und Steppe. Festschrift für Johan Callmer zum 65. Geburtstag. Internationale Archälogie. Studia honoraria 31 (Theune, C.-Biermann R.-Struwe-Jeute, G. H., edd.), 515-521. Rahden/Westf.

WURM, H. J.-LUDORFF, A., 1902: Die Bau- und Kunstdenkmäler des Kreises Minden. Münster.

ZÁRUBA, F., 2014: Hradní kaple I. - doba přemyslovská. Praha.

- 2017: Kaple a její úloha v rámci hradního areálu. In: Dvořáková, D. a kol., Stredoveké hrady. Život, kultúra, spoločnost', 99-114. Bratislava.

ŽEMLIČKA, J., 1998: Děkan Vít, hodnostář a dobrodinec pražské kapituly. Sonda do života významné kulturní osobnosti 13. století. In: Facta probant homines. Sborník k životnímu jubileu Prof. Dr. Z. Hledíkové, 549-569. Praha.

\section{Internetové zdroje}

Braathen Dendrokronologiska Undersökningar. Dostupné z: http://www.alfdendro.se/index.html https://monumentenregister.cultureKelerfgoed.nl/monumenten/24331

https://nl.wikipedia.org/wiki/Oldehove_(gebouw)

http://www.alfdendro.se/skara/husaby.html

\section{Zusammenfassung}

\section{Zur Frage der Kirchtürme}

In der Diskussion über die Anfänge der hochmittelalterlichen Burgen in den böhmischen Ländern wurde die Ansicht geäußert, dass romanische Emporenkirchen mit Westturm eine Vorstufe der Burg darstellen (Laval 2016, 47-90). Ein Kirchturm wird in diesem Zusammenhang als verständlicher Verweis auf einen Turm profanen Ursprungs verstanden. Seine Verbindung mit einer Kirche wird als das Ergebnis eines allmählichen Annäherungsprozesses zwischen Kirche und einem ursprünglich einzeln stehenden Turm profanen Zwecks angesehen. Die Verbindung des Gotteshauses mit einem Turm verleiht der Kirche eine Bedeutung, welche die symbolische Funktionsebene von hochmittelalterlichen Burgen vorwegnimmt. Der vorliegende Beitrag relativiert die Vorstellung, dass die zeitgenössische Wahrnehmung eines Kirchturms nur auf seine profane Funktionen verwies. Er fasst den Stand der Erkenntnisse über romanische Kirchen in Mitteleuropa knapp zusammen und weist besonders auf Arbeiten hin, welche einschiffige romanische Kirchen mit Westturm als Typ, ihren Ursprung und Verbreitung auf verschiedene Weise berührten. Der Beitrag korrigiert die Vorstellung, das Auftreten von kleinen Dorfkirchen mit Westturm und Empore sei ein charakteristischer Zug der Sakralarchitektur im engeren mitteleuropäischen Raum und spiegele eine Besonderheit lokaler kirchlicher Verhältnisse wider. Die Arbeit präsentiert deshalb eine Auswahl von in der tschechischen Literatur bislang unbekannten Kleinkirchen aus der Umgebung von Köln am Rhein (Wollersheim, Niederzündorf, Oberzündorf und Kleinbüllesheim), dem heutigen Belgien (Auderghem) und erwähnt auch Beispiele aus Schweden (Fjelie, Vä, Lyngsjö, Simris, Fjälkestad). Sie zeigt nicht nur hinsichtlich des Grundaufbaus von Schiff 
und Westturm eine Verwandtschaft auf, sondern auch in den Details der baulichen Anordnung der im ersten Stock der Westteile dieser Kirchen untergebrachten Emporen. Kirchen mit dieser Disposition begleiteten die Landgüter großer feudaler Eigentümer oder die Höfe lokaler Adeliger. Die Erkenntnisse zu ihrer Genese und Zusammenhänge ihres Auftretens stecken vorerst in den Anfängen. Die Erwägung gemeinsamer Inspirationsquellen bietet sich jedoch an. Im Beitrag wird ferner auf die Archaität der Verwendung von Türmen in der Sakralarchitektur hingewiesen, die in der Zeit, als auf dem Gebiet des böhmischen Staates die Adelssitze entstanden, bereits zu den charakteristischen und eingeführten Merkmalen gut ausgestatteter Sakralbauten gehörten. Die durch die Auswahl zeitgenössischer Beispiele belegte sakrale Ebene ihrer Symbolik erlangte in der vom Wirken der lateinischen Kirche beeinflussten Umgebung eine grundsätzliche und unübersehbare Bedeutung. Das geistliche Sendungsbewusstsein der Kirche schloss jedoch nicht aus, dass ihre repräsentative Erscheinung gleichzeitig als ständige Feier und dem Gedenken an den Gründer, Patron und ihre Familien gedacht war.

Die Hypothese von der allmählichen Annäherung zwischen profanem Turm und Gotteshaus wurde von der Auswahl der Kirchen gestützt, in deren Nähe sich ein Turm befindet. Die führende Stellung unter ihnen nimmt der westliche Doppelturm der Klosterkirche in Lorsch ein. In vorliegendem Beitrag wird auf Erscheinungsformen der Etappenhaftigkeit des Baus, ggf. Umbaus von Sakralbauten hingewiesen. Ihre Türme wurden in einigen Fällen im Hinblick auf eine beabsichtigte Vergrößerung des Baus im voraus und in zeitlichem Abstand zu älteren Bauten errichtet. Bei der Identifizierung einer entsprechendn Bauetappe können sie dann als einzeln stehende Gebilde wirken.

Zur weiteren Illustration der Hypothese über einen einzeln stehenden Turm profanen Zwecks, der sich der Kirche „,annähert“, dienten schwedische Kastalen. Im vorliegenden Beitrag wird auf die in Tschechien bislang nicht erwähnte Existenz romanischer Kirchen mit Westtürmen, teilweise mit erhalten gebliebenen Emporen oder Spuren von ihnen hingewiesen, die in Südschweden offenbar gleichzeitig mit einzeln stehenden Kastalen auftraten. Die Funktion der Kastalen ist Gegenstand einer langen und bisher nicht abgeschlossenen Diskussion. Ihr paralleles Auftreten mit Kirchtürmen zeugt jedoch von einer autonomen Stellung beider Bautypen.

Der vorliegende Beitrag erwähnt die Polyfunktionalität mittelalterlicher Bauten, die ihre dominante Bestimmung jedoch nicht verwischt. Auch bei Bauten mit sakralem Zweck kommen neben der hauptsächlichen Nutzung auch verschiedene Arten einer Übergangs- und Ausnahmenutzung in Betracht. Ihre Erscheinungsformen und baulichen Folgen haben die hauptsächliche also die sakrale Bedeutung - nicht unterdrücken müssen, konnten aber parallel zu ihr zur Geltung kommen. Die Frage der zeitgenössischen Rezeption dieser Bedeutungsschichten in verschiedenen kulturellen Kontexten und sozialen Milieus bleibt für weitere Diskussionen offen. Die repräsentative Bedeutung der romanischen Kirche, besonders in ihrer gemauerten Form, wird seit langem anerkannt. Die Nutzung der Kirche als Mittel, die elitäre Stellung des Gründers und Patrons sichtbar zu machen, geht der Etappe voraus, in welcher diese Rolle von der Burg übernommen wird. Auch trotz der Bedeutung der Repräsentationsabsicht, die Kirche und Burg miteinander verbindet, darf man nicht darüber hinwegsehen, dass es sich dabei um typologische Arten mit jeweils unterschiedlicher Hauptfunktion und unterschiedlicher Genese handelt.

doc. Ing. arch. Milena Hauserová, CSc., Ústav památkové péče Fakulty architektury Českého vysokého učení technického v Praze, Thákurova 9, 16634 Praha 6-Dejvice, Česká republika, milena.hauserova@fa.cvut.cz 
